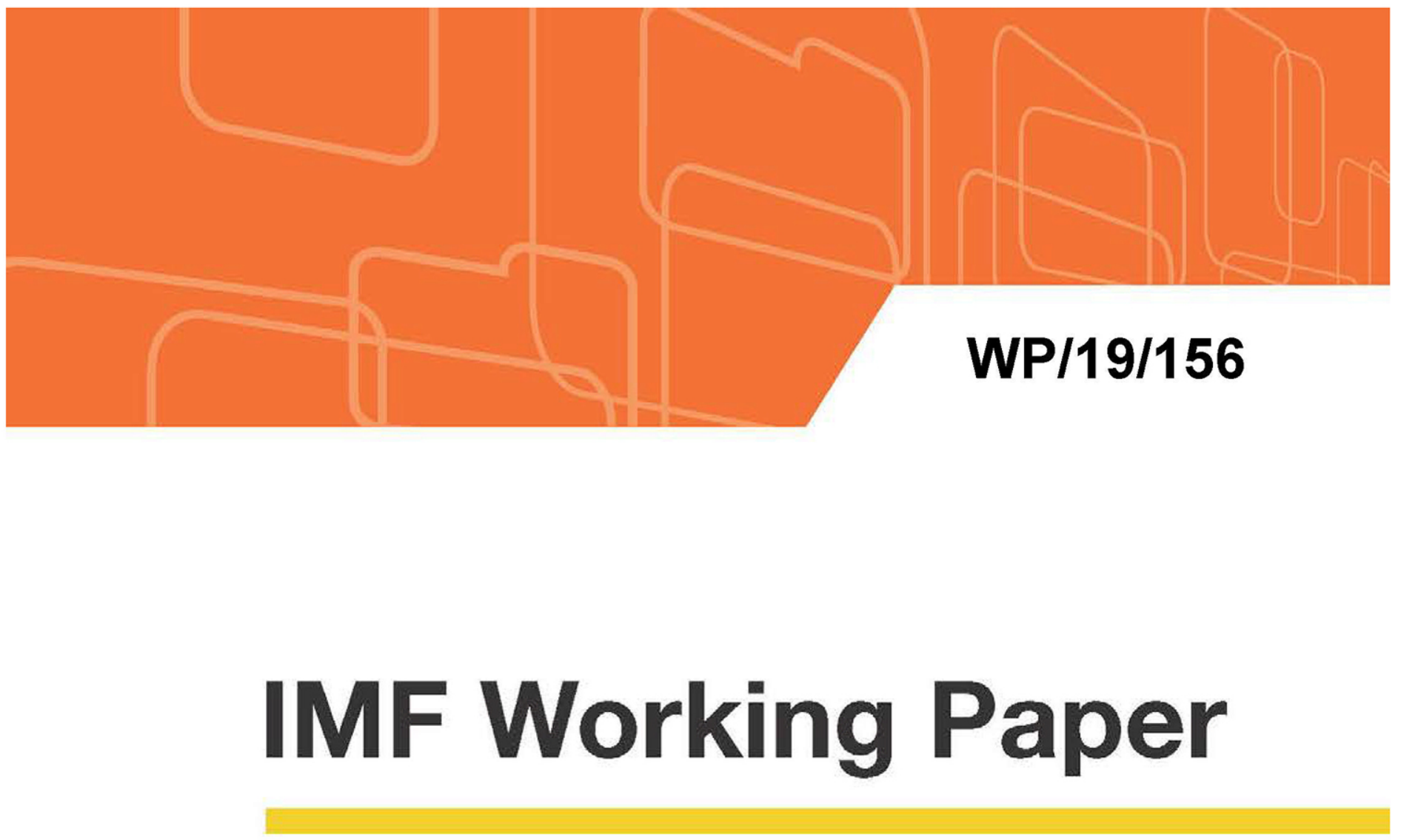

\title{
European Wage Dynamics and Spillovers
}

by Yuanyan Sophia Zhang

IMF Working Papers describe research in progress by the author(s) and are published to elicit comments and to encourage debate. The views expressed in IMF Working Papers are those of the author(s) and do not necessarily represent the views of the IMF, its Executive Board, or IMF management. 


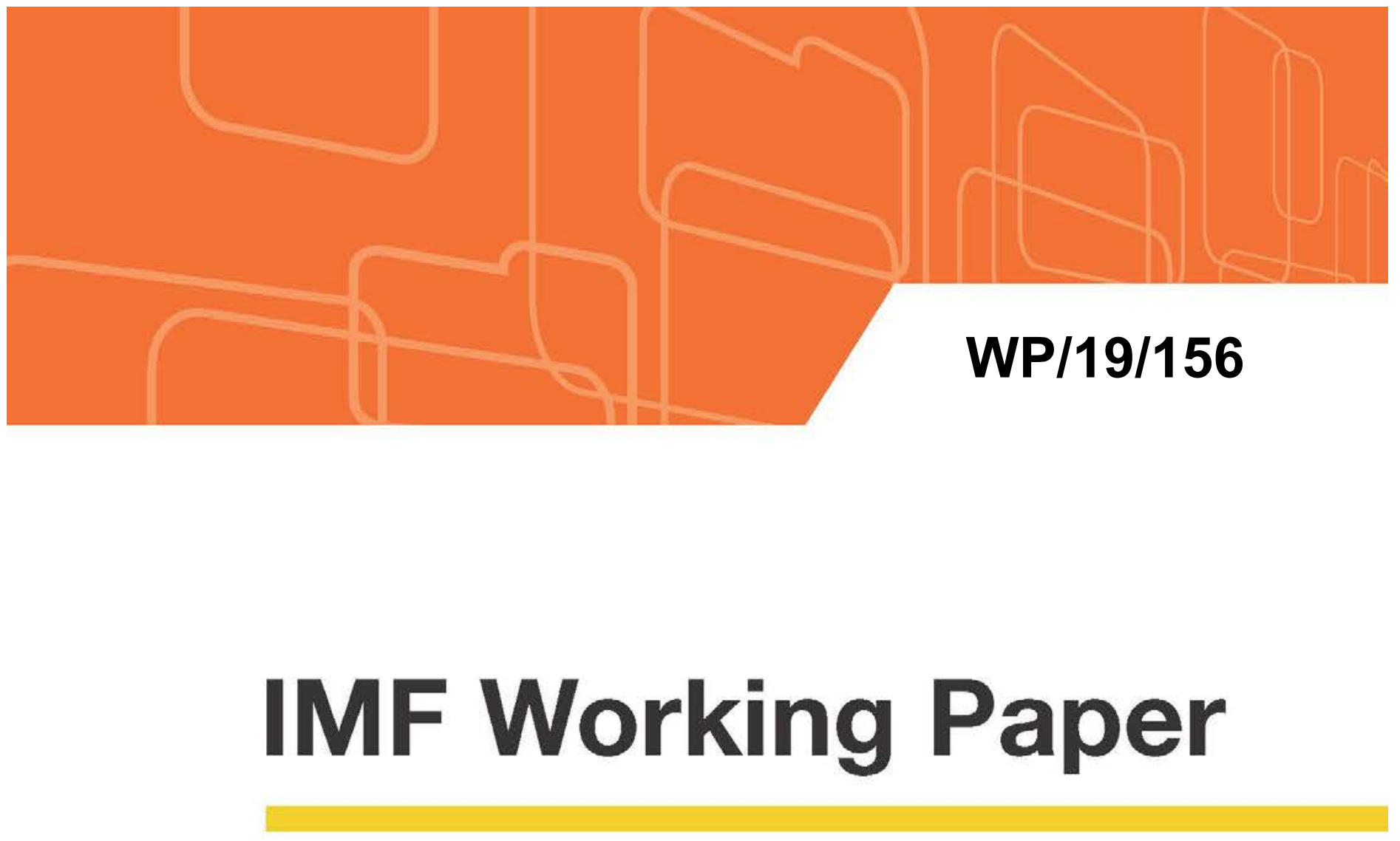

\section{European Wage Dynamics and Spillovers}

by Yuanyan Sophia Zhang

IMF Working Papers describe research in progress by the author(s) and are published to elicit comments and to encourage debate. The views expressed in IMF Working Papers are those of the author(s) and do not necessarily represent the views of the IMF, its Executive Board, or IMF management.

$$
\text { I N T E R N A T I O N A L M O N E T A R Y FU N D }
$$




\title{
IMF Working Paper
}

\author{
European Department
}

\section{European Wage Dynamics and Spillovers}

Prepared by Yuanyan Sophia Zhang ${ }^{1}$

July 2019

\section{IMF Working Papers describe research in progress by the author(s) and are published to elicit comments and to encourage debate. The views expressed in IMF Working Papers are those of the author(s) and do not necessarily represent the views of the IMF, its Executive Board, or IMF management.}

\begin{abstract}
Wage rises have remained stubbornly low in advanced Europe in recent years, but, at the same time, newer EU members are experiencing rapid wage acceleration. This paper investigates the drivers of this wage divergence. Econometric analysis using error correction models suggests that wage growth responds more quickly to changes in unemployment in the newer EU members than in advanced Europe, where wages are more closely related to inflation and inflation expectations in the short run, implying greater inertia in nominal wage rises in advanced Europe. In the years after the global crisis, this inertia contributed to the build up of a real wage overhang relative to sharply slowing labor productivity, which subsequently dragged on nominal wage rises even as unemployment began to decline. Spillovers of subdued wage growth between euro area countries also weighed on wage rises in advanced Europe.
\end{abstract}

JEL Classification Numbers: J3, J6, F22

Keywords: wages, spillovers, Phillips curve, non-employment, European Union Author's E-Mail Address: yzhang@imf.org

\footnotetext{
${ }^{1}$ The author is grateful to Craig Beaumont for insightful discussions and helpful comments throughout the project. The paper also benefits from helpful discussions with Jorg Decressin, Jean-Marc Natal, Emil Stavrev, and participants at the IMF departmental seminar. Vizhdan Boranova and Nemanja Jovanovic provided excellent research assistance. All remaining errors are my own.
} 


\section{Contents}

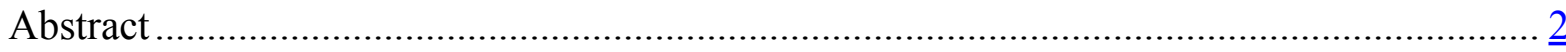

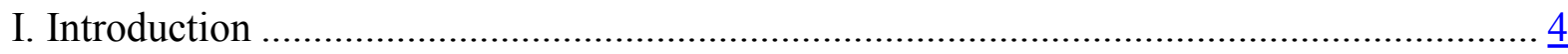

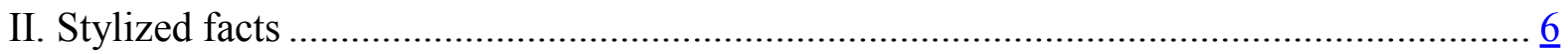

III. Data and Econometric Specifications ............................................................ 10

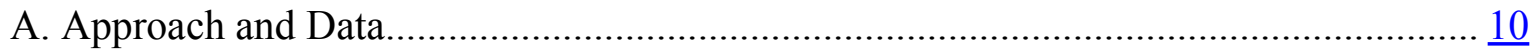

B. Econometric Specifications .................................................................................. 11

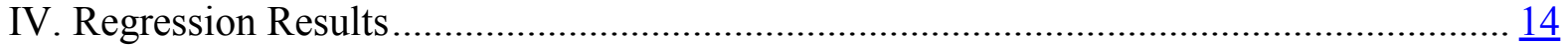

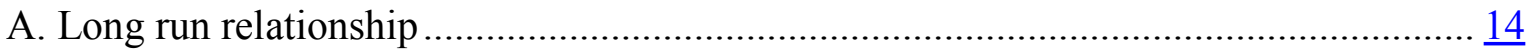

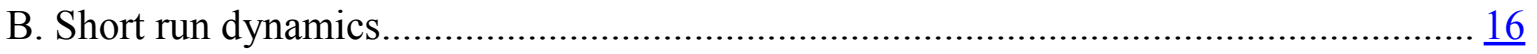

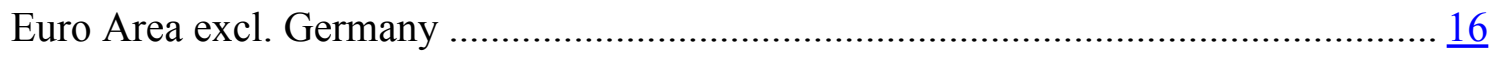

Newer EU Members .................................................................................. 17

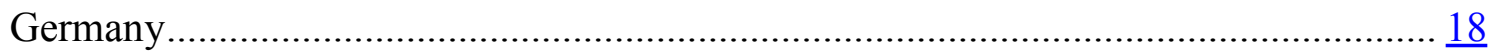

V. Factors Driving Wage Growth ........................................................................ 19

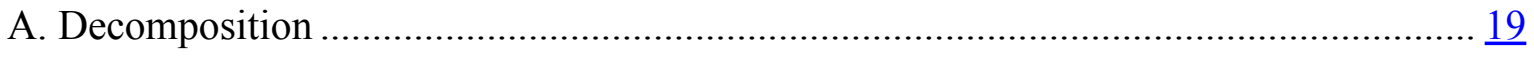

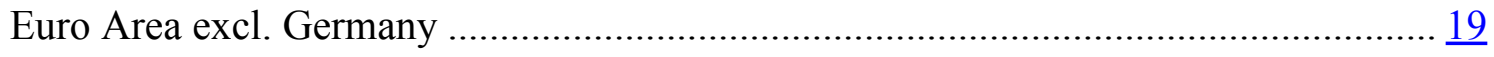

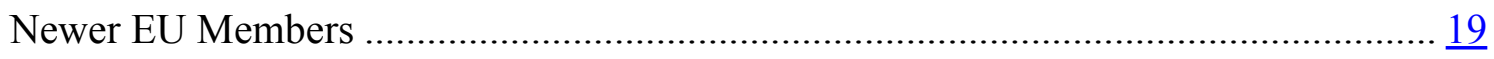

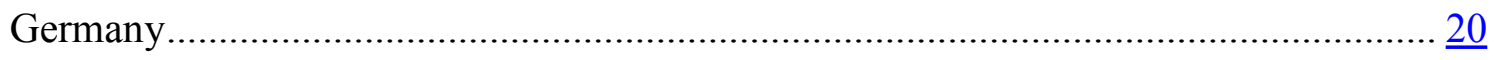

B. Regional Differences in Wage Growth ......................................................... 21

C. Simulation of Spillovers ................................................................................ 22

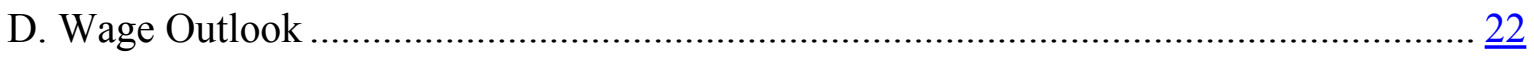

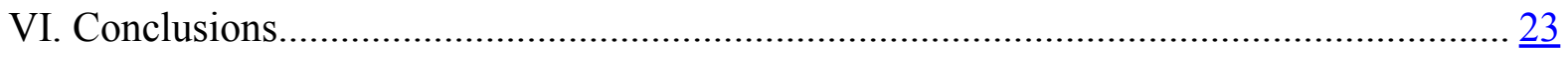

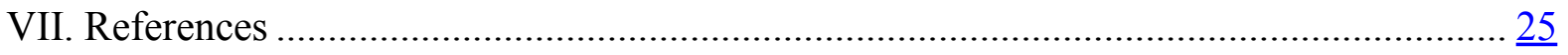




\section{INTRODUCTION}

Labor market conditions in advanced Europe have improved significantly in recent years, but wage rises remained stubbornly low. Employment has grown rapidly, and surveys have shown rising labor shortages in many countries. Unemployment rates have fallen from around 11 percent in 2013 to less than 8 percent by 2018 (Figure 1.1). For many countries, it is estimated that unemployment has returned to equilibrium or structural levels. However, wage growth has remained stagnant. In the EU15 (long-standing EU member countries) nominal wage increases have stayed below 2 percent since 2012 and, at 1.7 percent in mid-2018, were only half of pre-crisis (2001-08) average growth rates

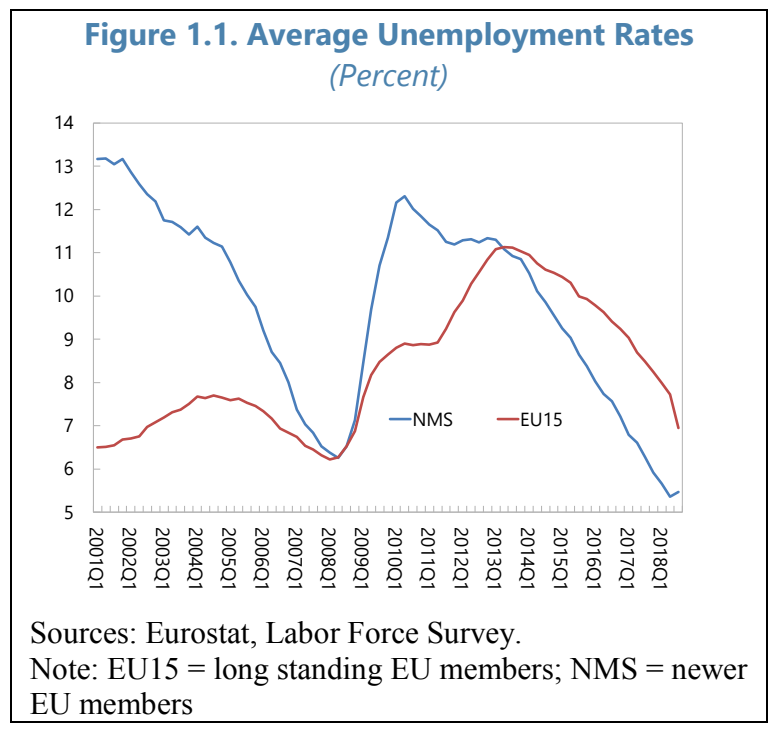
(Figure 1.2). ${ }^{2}$

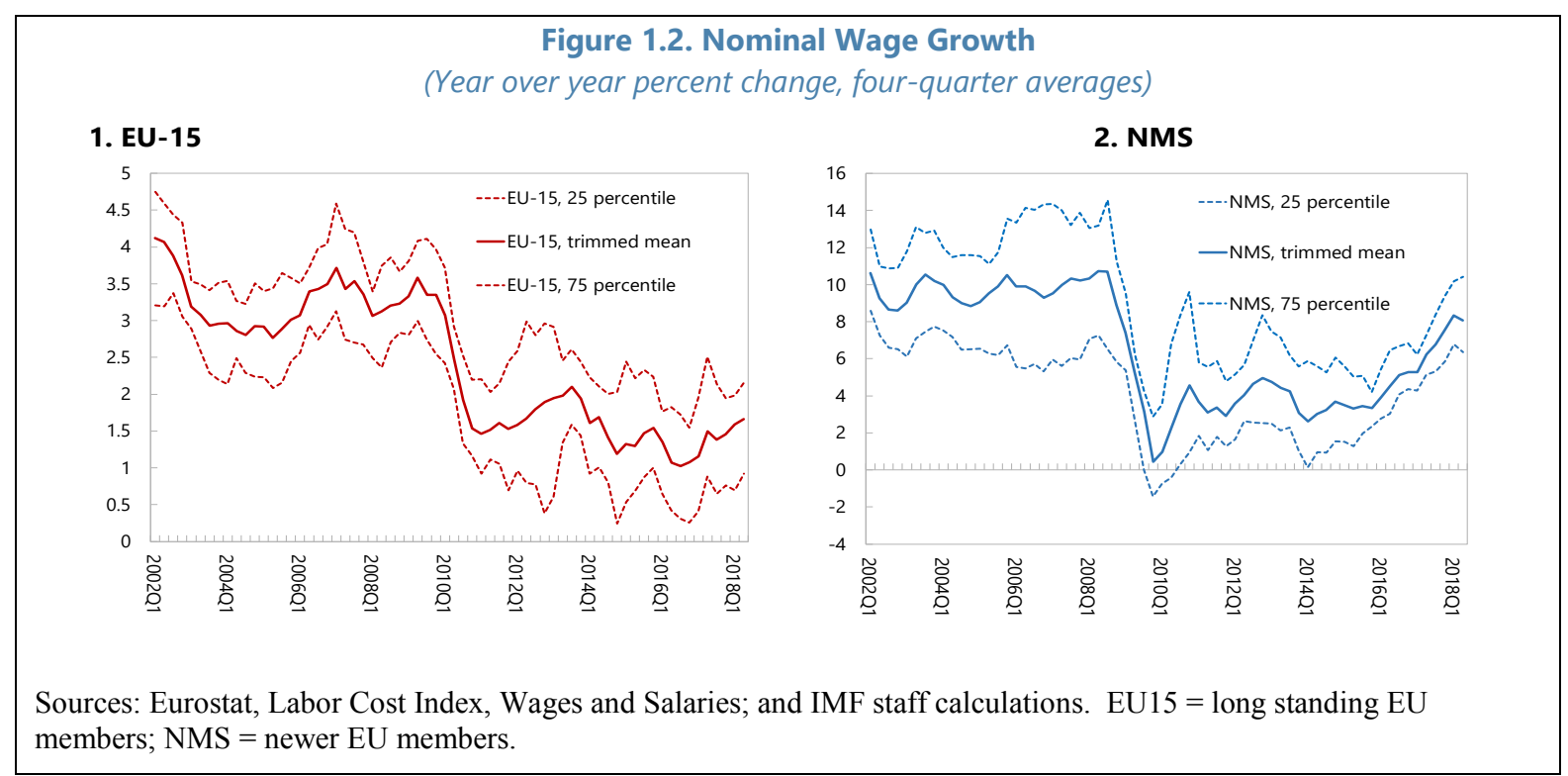

\footnotetext{
${ }^{2}$ Newer EU members (NMS) are Bulgaria, Croatia, the Czech Republic, Estonia, Hungary, Latvia, Lithuania, Poland, Romania, the Slovak Republic, and Slovenia. EU15 members are Austria, Belgium, Denmark, Finland, France, Germany, Greece, Ireland, Italy, Luxembourg, the Netherlands, Portugal, Spain, Sweden, and the United Kingdom. Cyprus, and Malta are not included in this analysis because special factors affect GDP dataand hence labor productivity — such as multinationals in Ireland and the gaming industry in Malta.
} 
Figure 1.3. Real Product Wage Growth

(Year over year percent change, four-quarter averages)

\section{EU-15}

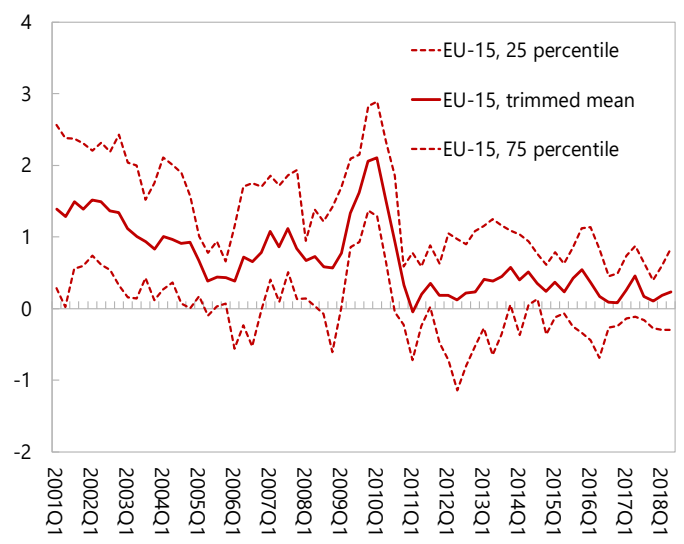

2. NMS

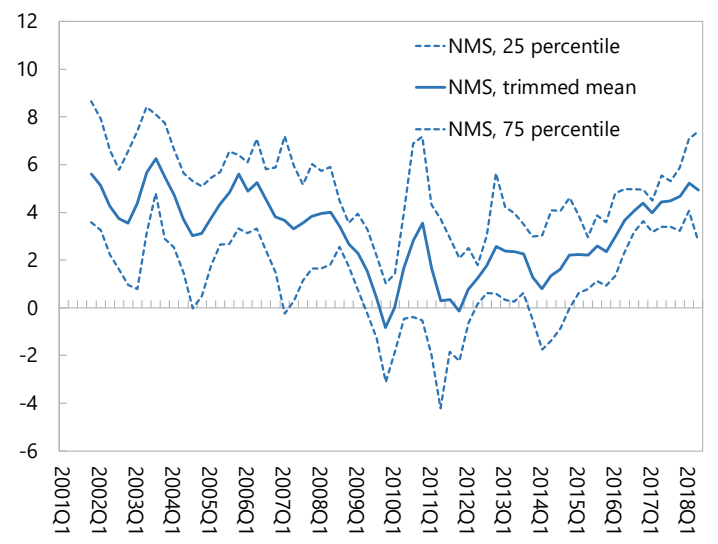

Sources: Eurostat, Labor Cost Index, Wages and Salaries; and IMF staff calculations. EU15 = long standing EU members; NMS = newer EU members

In contrast, wages are growing notably faster in the newer EU members. Moreover, the pace of wage growth has accelerated, with average wage increases reaching over 8 percent by mid-2018 from 3 percent in 2014. This rise in wage growth was led by the Baltics and southern European countries, with wages in central European countries picking up in more recent years. This divergence between the EU15 and newer EU members is also evident in real product wages (deflated by the GDP deflator): annual rates of growth averaged less than $1 / 2$ percent in the EU15 in mid-2018, little changed from 2014, but surged from 3 percent to close to 6 percent during the same period in the newer members (Figure 1.3). The more rapid wage increases could reflect to the sharper decline of unemployment rates-by 6 percentage points on average since 2013, compared with a 4 percentage point fall in advanced Europeyet this difference seems insufficient to account for the scale of the divergence in wage rises.

Wage moderation in the advanced economies has been extensively analyzed in the literature (e.g. IMF 2017a), which finds low inflation, slowing productivity growth, and remaining slack in labor markets to be the main contributors. On the latter, a range of indicators of underemployment, such as involuntary part-time employment, hours worked per person, etc., suggest that labor market conditions are not as tight as the rapid fall in unemployment rates would imply (IMF 2017a, IMF 2018, Bell and Blanchflower 2018). Cross-border spillovers from slack in foreign labor markets, and from wage moderation in countries that are trade competitors, are also found to contribute to slower domestic wage pick-ups in recent country studies (e.g. Sweden (Zhang 2017), UK (Chen 2018), and the Netherlands (Zhang 2018)). In contrast, few studies have investigated the fundamental drivers of strong wage recovery in the newer EU members.

The main contribution of this paper is to analyze the factors driving wage dynamics in both the EU15 and newer EU members, helping understand the divergent wage outcomes in these regions. In view of the potential for wages to temporarily be away from equilibrium, especially given Europe's double-dip recession and nominal wage rigidities, the paper uses an error correction model (ECM) approach, which links real product wages to labor 
productivity in long-run equilibrium. Drawing on a range of recent research, the paper analyzes the relevance of broader indicators of labor market slack than unemployment, with wage dynamics also linked to inflation expectations as in a wage Phillips curve. There is significant labor mobility within the EU region and firms are competing with firms in other EU countries, both within the EU and in international markets. Accordingly, unlike most analysis of national wages, the paper analyzes the importance of cross-border spillovers from external labor market conditions, migrant flows, and external wage developments.

\section{STYLIZED FACTS}

In the EU15 countries, average nominal wage growth has remained around $1 \frac{1}{2}$ percent since 2011, down from just over 3 percent during 2003-09 (Figure 2.1). ${ }^{3}$ This sizable slowing in nominal wage growth coincides with lower inflation in output prices (down 1 percentage point to about $1 \frac{1}{4}$ percent in recent years) and slower trend productivity growth (down $1 / 2$ percentage point to 0.6 percent).

But real wage growth has remained below the trend growth in labor productivity as reflected in a declining ratio of real wages to trend productivity since the global financial crisis (Figure 2.1, panel 6), which continued until recently despite a sizeable decline in unemployment. It is notable that this decline followed a significant rise in the wage/productivity ratio in the immediate wake of the global financial crisis, which arose because solid nominal wage growth continued for a time even as inflation slowed and trend productivity flattened. This inertia in nominal wage rises may reflect overlapping contracts and downward wage rigidities. The resulting build-up of an "overhang" in real wages relative to labor productivity after the crisis may be one contributing factor to the subsequent subdued wage growth. Only in 2017-18 has this ratio appeared to stabilize, suggesting that the period of real wage adjustment may be completed.

In contrast, wage increases in newer EU members have picked up strongly in recent years as unemployment has fallen to low levels (Figure 2.2). Looking back to the global financial crisis, a more rapid decline in nominal wage increases ensured that there was no lasting real wage overhang in the newer EU members. During 2011-15, nominal wage growth of about $3 \frac{1}{2}$ percent kept real wages stable relative to productivity, with the level of this ratio about 1 percent below historical norms - reflecting the period of high unemployment in the newer members after the crisis. But nominal wage growth picked up rapidly in 2016-17, exceeding 8 percent year over year by mid-2018. This wage acceleration followed a steep decline in unemployment, averaging 6 percentage points since the end of 2012, bringing unemployment down to an average of 5.5 percent by mid-2018, in line with pre-crisis lows.

\footnotetext{
${ }^{3}$ Nominal wages are measured as labor compensation (including employers' social security contributions) per employee hour worked.
} 
Figure 2.1. EU-15: Wages and Traditional Drivers
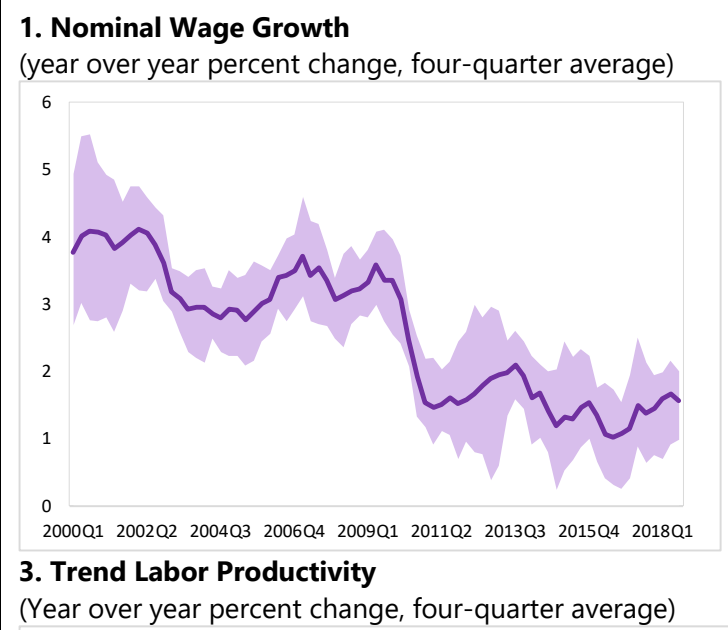

\section{GDP Deflator Inflation}

(Year over year percent change, four-quarter average)

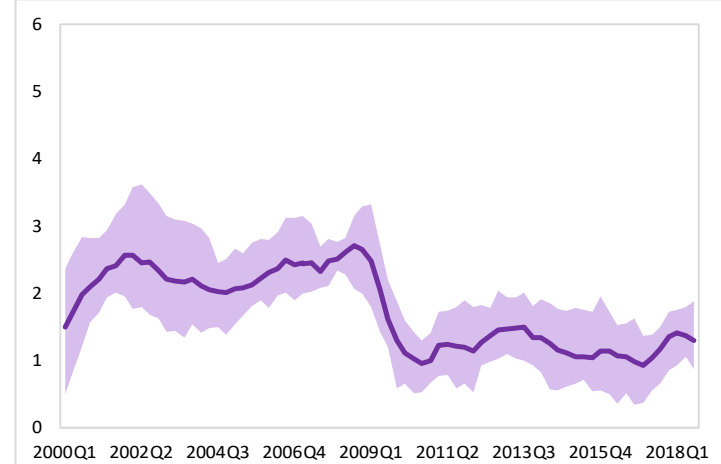

\section{Unemployment Rate}

(Percent, seasonally adjusted)

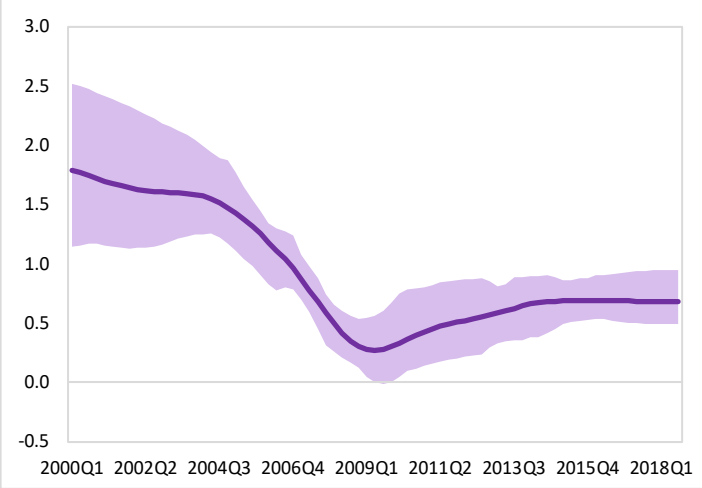

\section{Real Product Wage Growth}

(Year over year percent change, four-quarter average)
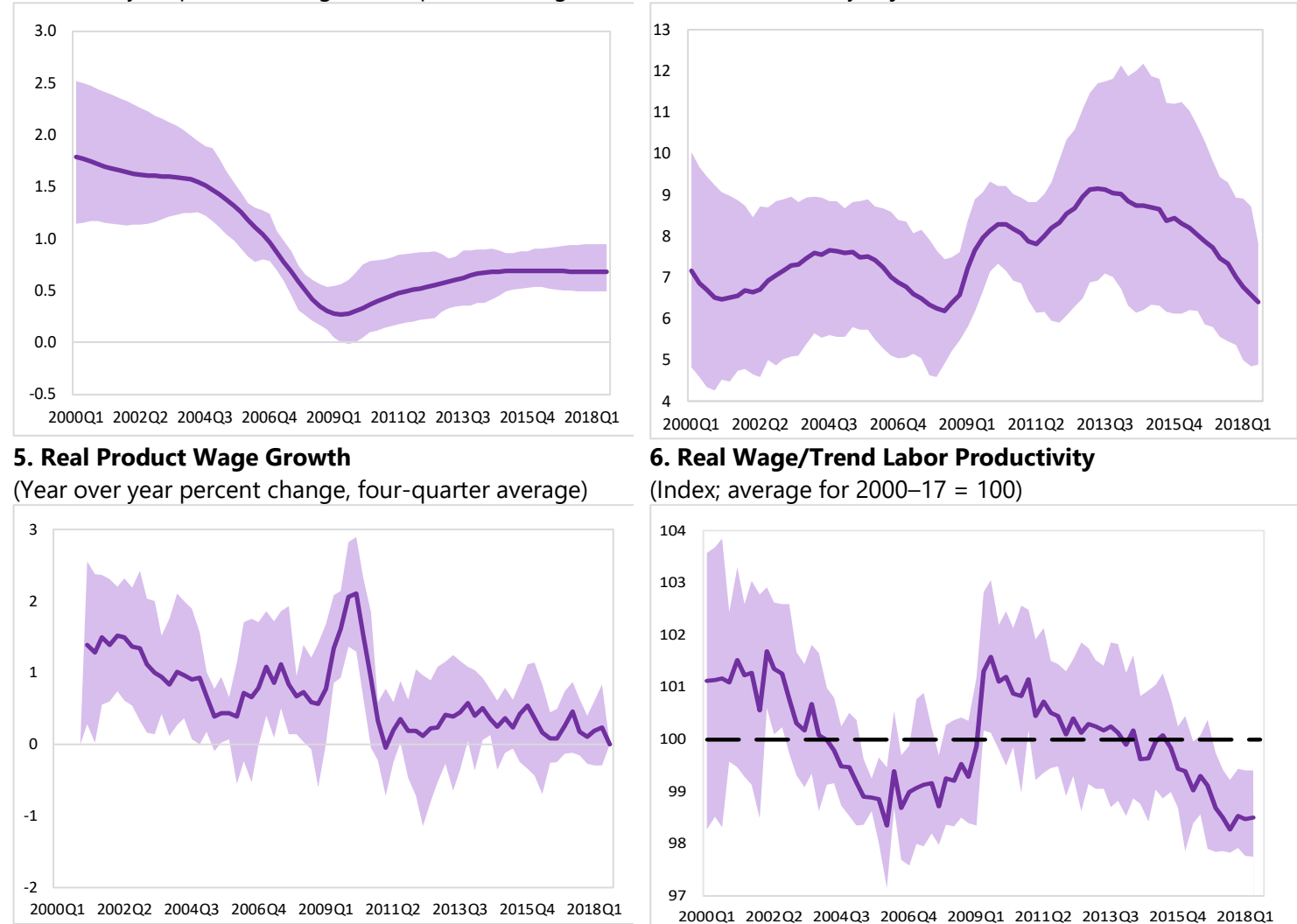

\section{Real Wage/Trend Labor Productivity} (Index; average for 2000-17 = 100)

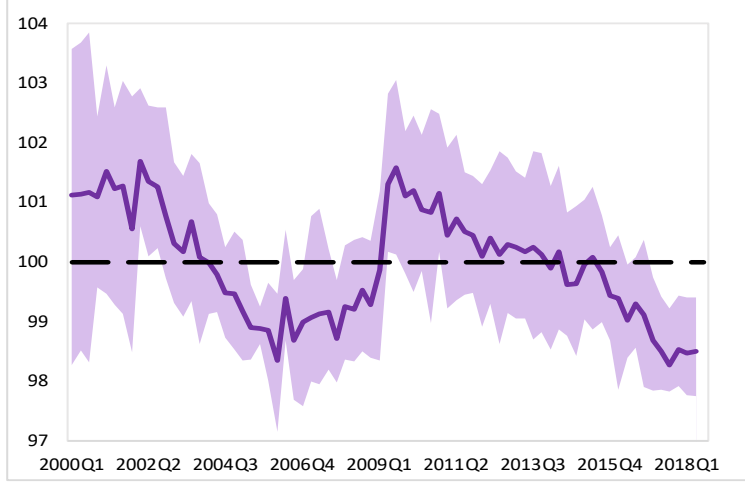

Sources: Eurostat, Labor Cost Index, Wages and Salaries; and IMF staff calculations. Footnote 1 defines EU15 and NMS.

Note: NAIRU = nonaccelerating inflation rate of unemployment; EU15 = long standing EU members; NMS = newer EU members; OECD = Organization for Economic Co-operation and Development.

Define variables, e.g. trend labor productivity

With inflation in NMS countries rising only modestly in the recent years, real wage gains also surged to almost 6 percent year over year by mid-2018, well above estimates of trend productivity growth, which averaged about 2 percent, much lower than the pre-crisis level. As a result, the average ratio of real wages to trend labor productivity was roughly $2 \frac{1}{2}$ percent higher than its historical average in 2017, a level exceeded only in mid-2008 for just two quarters, with further substantial increases in 2018. 


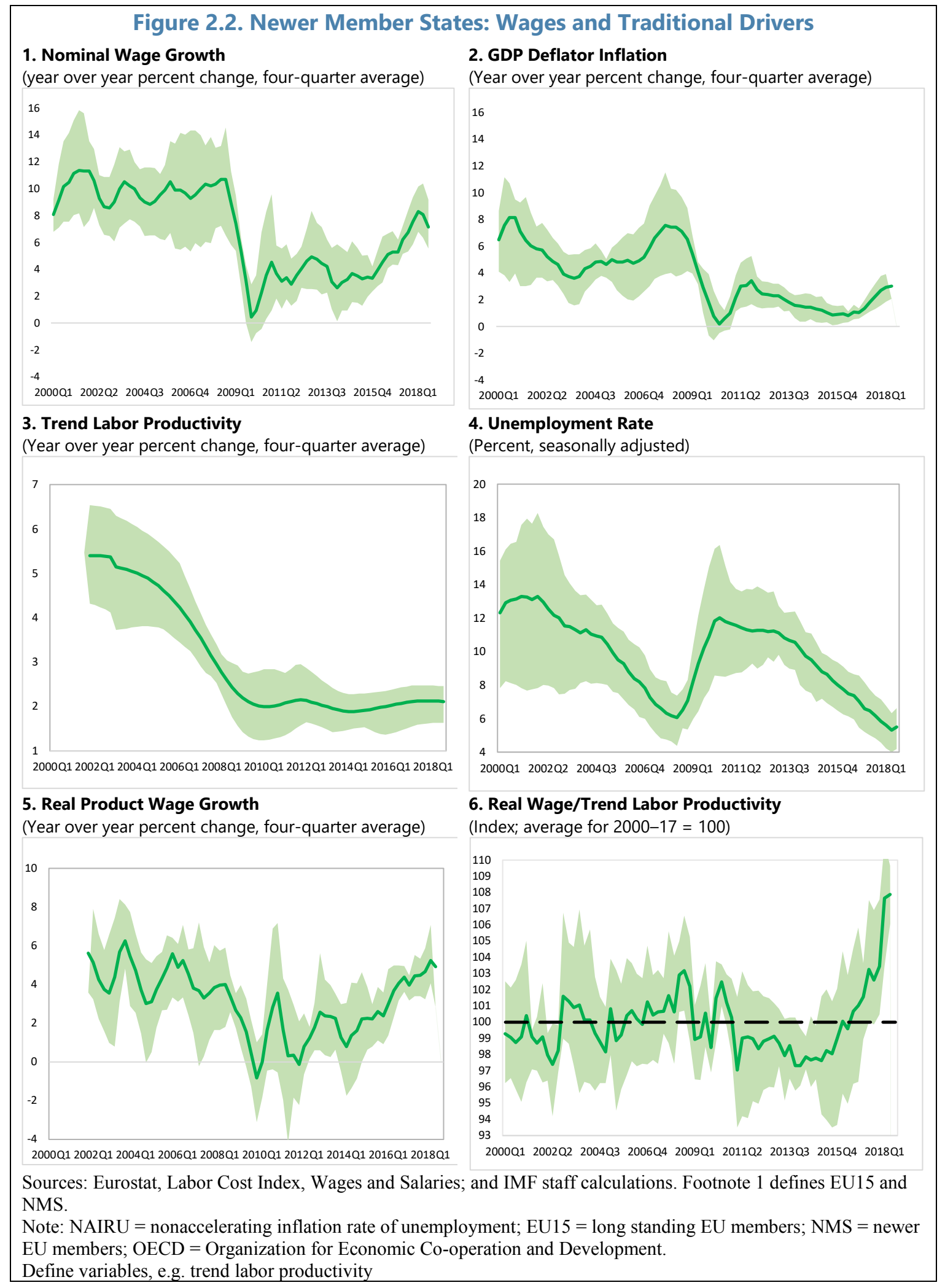

CInternational Monetary Fund. Not for Redistribution 
Both unemployment gaps and surveys of labor shortages indicate tighter labor market conditions in the newer EU members relative to the EU15 (Figure 2.3). ${ }^{4}$ Slack in those countries is estimated to have largely disappeared by about mid-2015, which is consistent with the timing of the wage acceleration in recent years. ${ }^{5}$ Labor shortages exceed pre-crisis peaks in the newer EU members — being especially strong in industry - which may help explain the recent acceleration of real wage growth in these countries.

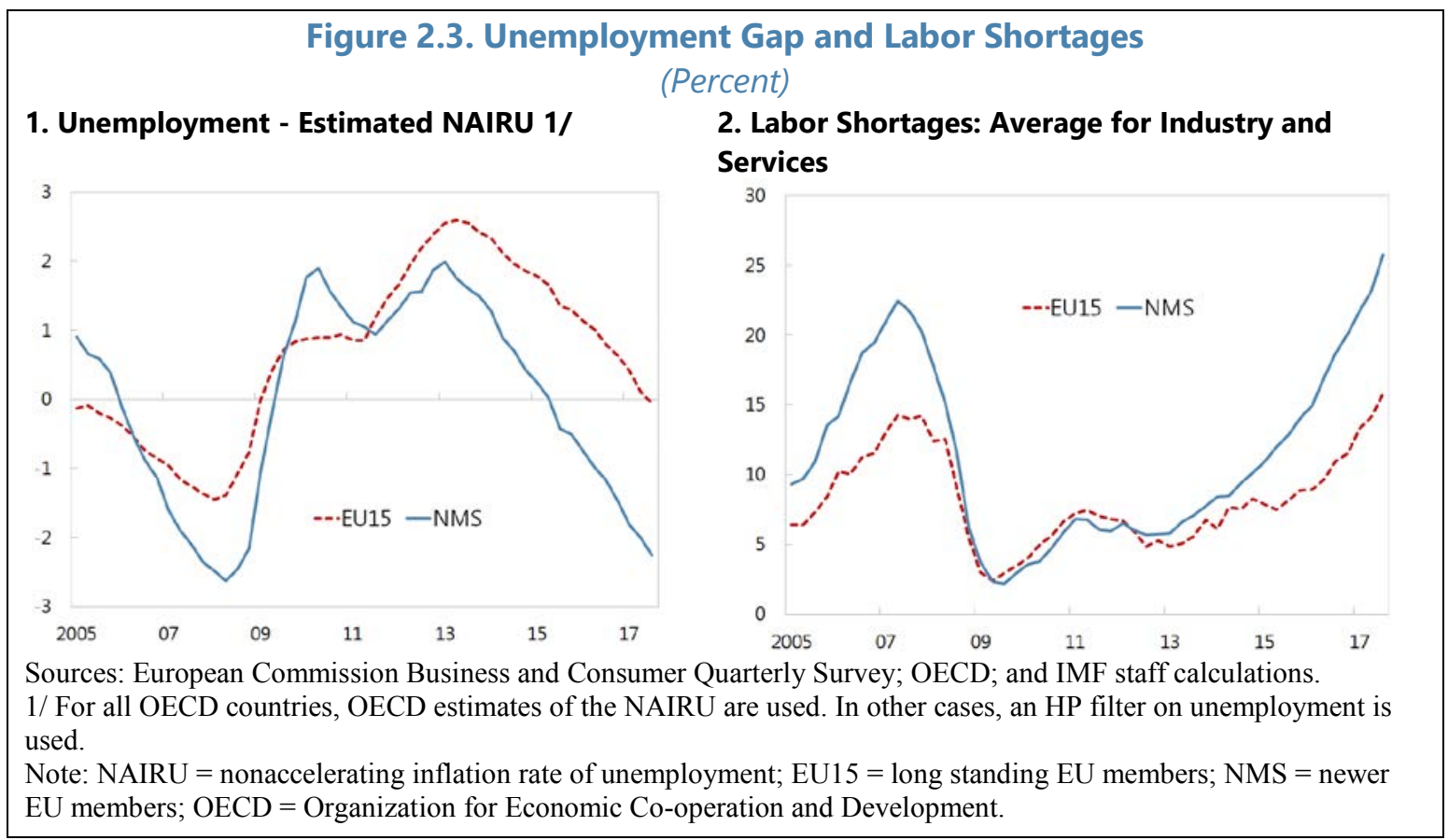

Yet other domestic factors and perhaps spillovers from the EU15 labor market recovery could also be at work in the new member states. For example, various country case studies found that foreign labor market conditions and wage growth also have significant impact on domestic wage developments, e.g. Sweden (Zhang 2017), and the Netherlands (Zhang 2018). The remainder of the paper tests these hypotheses in more a rigorous econometric setting.

\footnotetext{
${ }^{4}$ Unemployment gaps are subject to uncertainty around the NAIRU, which is based on Organisation for Economic Co-operation and Development (OECD) estimates for OECD members and Hodrick-Prescott (HP) filters for other countries. Analytical results are similar when applying an HP filter in all cases.

${ }^{5}$ Analysis of the correlations between real wages (as deviations from trend productivity) and unemployment gaps finds that these correlations are initially higher in newer EU members and that they peak after six quarters; in EU15 countries these correlations start lower and peak after eight quarters (IMF 2018).
} 


\section{Data And EConometric Specifications}

\section{A. Approach and Data}

The Phillips curve - which focuses on wage responses to inflation, inflation expectations, and to domestic unemployment - is widely used in the empirical literature on wages. ${ }^{6}$ This paper extends the analysis of wages in several directions: (i) broader measures of slack than unemployment; (ii) cross-border spillovers; and (iii) effects of deviations from long-run equilibrium owing to sizable shocks such as the global financial crisis. As this analysis entails estimating more parameters than a standard Phillips curve, a regional panel model is used to seek more robust results than single country models. Germany is the exception that is modelled separately because it is often considered to be the wage leader in the region.

The analysis covers three groups of countries - (1) Germany; (2) a panel of other Euro Area countries (Austria, Belgium, France, the Netherlands and Spain); (3) a panel of new EU members (Czech Republic, Estonia, Hungary, Latvia, Lithuania, Poland, Slovak Republic and Slovenia). Italy was initially included in the second panel, but the trend level of labor productivity has risen only 1 percent cumulatively since 2002 , resulting in unreliable estimates of the long-term impact of productivity on real wage levels. ${ }^{7}$ The sample period is from 1995:Q1 to 2017:Q3.

The key wage measure used in the analysis is total labor compensation (national accounts) per employee hour worked. Total labor compensation includes social security contributions of employers and other non-wage benefits such as bonuses, sick leave pay, etc. Other wage measures, including wages and salaries per employee hour and the labor cost index were also tested, and the results are broadly consistent with those using total labor compensation.

Traditional Phillips curve models include inflation and/or inflation expectations, and the unemployment rate or an unemployment gap relative to structural unemployment. The HIPC measure of inflation is used for all countries in the short-run analysis, as it is the most widely recognized measure of inflation. ${ }^{8}$ One-year-ahead Consensus Forecasts for inflation from professional forecasters are used as a proxy for short-term inflation expectations, as survey data for expectations of households or businesses are not available for all countries. ${ }^{9}$ Unemployment gaps are the difference between the actual unemployment rate and structural unemployment (NAIRU) estimates by the OECD or using an HP-filter when OECD estimates are not available. ${ }^{10}$ As in IMF (2017a), the traditional Phillips curve is augmented to include trend growth in hourly labor productivity, as earlier analysis had

\footnotetext{
${ }^{6}$ IMF (2017a), Blanchard and Katz (1999).

${ }^{7}$ Kangur (2018) finds that Italian wages show low responsiveness to firm-specific productivity, regional disparities, and skill mismatches and that rigid nominal wages imply that adjustment occurs through lower profits and employment.

${ }^{8}$ In the long-run analysis, real wages are calculated using the GDP deflator, i.e., the price of domestic production, consistent with the measurement of labor productivity as GDP per hour worked.

${ }^{9}$ The possibility to use two-year-ahead forecasts was explored as these might better reflect the expectations guiding wage negotiations, which are sometimes for periods exceeding a year. But data coverage for one-yearahead forecasts is substantially better and one-year projections are highly correlated with two-year projections.

${ }^{10}$ OECD. stat Economic outlook forecasts of equilibrium unemployment.
} 
found a dramatic deceleration in productivity growth after the crisis, which could contribute to subdued wage growth.

Since the crisis, the literature finds that unemployment rates may not fully capture the changing slack in the labor market. For example, declines in the labor participation rate in the U.S. have drawn attention to persons not included in unemployment that remain marginally attached to the labor market. In some countries, there has been a shift from regular contracts to temporary contracts, self-employment, and part-time jobs. If such workers are not fully employed, so that they would be available for full-time regular work or be willing to work longer hours, the underlying labor market slack is higher than suggested by the unemployment rate, and changes in the unemployment rate may not fully capture changes in slack. In fact, Chapter 2 of the October 2017 WEO (IMF 2017a) finds that involuntary part-time employment weighs on wage growth. In addition, wages in the U.K. (Chen 2018) and the Netherlands (Zhang 2018), are sensitive to cyclical swings in self-employment.

To capture slack in a parsimonious manner, the paper uses a non-employment index described in chapter 2 of the April 2018 Regional Economic Outlook for Europe (IMF 2018b). This index combines the unemployment rate, marginally attached workers (those who are not unemployed under typical labor force surveys, but intend to work), and involuntary part-time employment, seeking to provide a better indicator of labor market slack. In addition, Bulligan, Guglielminetti, and Viviano (2017) finds that the intensive margin, or hours worked per person, is relevant for wage growth, suggesting it is a further indicator of labor market slack. A simple correlation analysis finds that each slack indicator contains significant non-overlapping information, so this paper tests their relevance in the wage equation alongside the unemployment rates.

Cross-border spillovers in wage formation might reflect transmission via migration and hence labor supply changes. International transmission may also run through goods markets, as wage negotiators take into consideration the competitiveness of firms and hence the security of employment. Foreign labor market conditions are proxied by a GDP-weighted average of euro area unemployment rates. Data on migrant flows is from Eurostat, which has a good country coverage. But, with the latest available update covering data until 2015, the impact of migration in the most recent years cannot be tested. A GDP-weighted average of euro area wages is used to capture spillovers from foreign wage developments. German wages, which are closely monitored by wage setters in many European countries, are also tested as a source of spillovers. Yet, wage setting in some countries, such as Belgium, follows not only German wages but also those in France and the Netherlands. ${ }^{11}$

\section{B. Econometric Specifications}

The dynamics of nominal wages are examined using an error-correction model (ECM). In comparison with $\operatorname{IMF}(2017 \mathrm{a})$, which augmented a wage Phillips curve to include trends in productivity growth, the ECM includes a further term to capture any deviations in real

\footnotetext{
${ }^{11}$ Further information is provided in the IMF's 2017 Article IV Consultation for Belgium (IMF 2017c, Box 2). The 1996 Indexation and Competitiveness law states that the forecast weighted growths of foreign hourly labor costs in national currency (that is weighted average for France, Germany and the Netherlands) acts as an upper limit for wage negotiations at all levels (macro, sector, and company). Source: Eurofound.
} 
product wages from their estimated long-run equilibrium level. ${ }^{12}$ Over the longer term, real product wages, calculated as the nominal wage deflated by the GDP deflator, are expected to be primarily driven by trends in labor productivity, i.e., excluding cyclical swings in productivity due to variations in resource utilization. This expectation is supported by the relatively small variations of the ratio of real wages to trend labor productivity over time and across countries (Figures 2.1, 2.2).

Nonetheless, structural changes in the labor market can sometimes lead to structural shifts in equilibrium real wage levels. Hence for the euro area countries, labor market reforms are also controlled for using a database on major reforms (IMF 2017b). For smaller EA countries, spillovers from wages in the region or other countries in the long run are also explored. For the newer EU members, the long run real wage equation only includes domestic productivity as wage convergence to the advanced EU levels hinges primarily on productivity convergence. No reform dummy is included as newer EU members' labor markets tend to be more flexible, with no major reforms evident in the sample period. This gives the following long-run specification:

$$
\ln R W_{t}=\alpha+\beta_{1} \ln P t v y_{t}^{\text {trend }}+\beta_{2} \text { Reform }_{t}+\beta_{3} \ln R W_{f, t}+E C M_{t}
$$

where $R W$ is the real product wage (deflated by GDP deflator), trend productivity (Ptvy ${ }^{\text {trend }}$ ) is calculated using the Hodrick-Prescott filter with a lambda parameter of 1600, the reform dummy equals one during the period of the first reform in the sample, increases to two during the second reform and continues to accumulate until the end of the sample period. $R W_{f}$ is the foreign real product wage. $E C M_{t}$ is the stationary deviations from long run equilibrium.

The focus of the analysis of short-run wage dynamics is the growth rate of wages over four quarters, rather than a single quarter, to reflect widespread practices in wage setting. In common with IMF (2017a), the key explanatory variables are, lagged wage growth, lagged inflation, inflation expectations, growth in trend productivity, and the unemployment gap (level and change). Under the ECM setup, the fourth lag of error correction term from the long run regression is also included. Lags for the other explanatory variables are mostly 4 quarters, but sometimes range between 3-5 quarters depending on the significance level. Panel estimation is used to allow for sufficient degrees of freedom given the richness of the parameters.

This gives a baseline specification as follows, where $\mathrm{d}$ denotes the 4-quarter difference:

$$
\begin{aligned}
& d \ln W_{t}=\alpha+\beta_{0} d \ln W_{t-4}+\beta_{1} d \ln P t v y_{t-L}{ }^{\text {trend }} \\
& +\beta_{2} d \ln H I C P_{t-L}+\beta_{3} \operatorname{expinf}_{t-L} \\
& +\beta_{4} U_{g a p, t-L}+\beta_{5} d \ln U_{t-L}+E C M_{t-4}+\varepsilon_{t}
\end{aligned}
$$

\footnotetext{
${ }^{12}$ Modeling the level of real product wages implies a restriction that nominal wages respond to the GDP deflator with a unity coefficient in the long run, consistent with economic theory. But the short-term error correction models of nominal wage growth allow real wages to be affected temporarily by inflation shocks (see Blanchard and Katz, 1999).
} 
Richer versions of the model are estimated in a step-by-step approach. In the next step, the impact of broader labor market slack is assessed by extending the baseline model to include alternative labor slack indicators. The non-employment (NE) index is first tested as an alternative to headline unemployment. The difference between actual hours worked per employee and its trend level ( Hour $_{\text {gap }}$, ) is also included separately to test its explanatory power beyond non-employment.

$$
\begin{aligned}
& d \ln W_{t}=\alpha+\beta_{0} d \ln W_{t-4}+\beta_{1} d \ln P t v y_{t-L} \text { trend } \\
& +\beta_{2} d \ln H I C P_{t-L}+\beta_{3} \operatorname{expinf}_{t-L} \\
& +\beta_{4} N E_{g a p, t-L}+\beta_{5} d \ln N E_{t-L}+\beta_{6} H_{o u r} r_{g a p, t-L}+E C M_{t-4}+\varepsilon_{t}
\end{aligned}
$$

Last but not least, cross-border spillovers from external unemployment and wages and migration flows are estimated. On top of the preferred specification (1.3) tested above, weighted-averages for wage growth $\left(W_{f}\right)$ and changes in the unemployment rate $\left(U_{f}\right)$ in the euro area are included.

$$
\begin{aligned}
& d \ln W_{t}=\alpha+\beta_{0} d \ln W_{t-4}+\beta_{1} d \ln \text { Ptvy }_{t-L}{ }^{\text {trend }} \\
& +\beta_{2} d \ln H I C P_{t-L}+\beta_{3} \operatorname{expinf}_{t-L} \\
& +\beta_{4} N E_{g a p, t-L}+\beta_{5} d \ln N E_{t-L}+\beta_{6} \text { Hour }_{g a p, t-L} \\
& +\beta_{7} d \ln W_{f, t-L}+\beta_{5} d U_{f, t-L}+E C M_{t-4}+\varepsilon_{t}
\end{aligned}
$$

After controlling for such spillovers, the impact of migration flows is examined, using lagged data to reduce endogeneity problems given that migration is responsive to the strength of labor demand. 


\section{REGRESSION RESULTS}

\section{A. Long run relationship}

Labor productivity is the primary determinant of real wages in the long run. ${ }^{13}$ For many countries, labor market reforms and wage spillovers are also found to affect the level of real wages (Table 4.1).

- In Germany, the estimated elasticity of real wages to productivity is close to unity in the long run. The Hartz reforms implemented in 2003-05 are found to lower the equilibrium real wages by $5 \frac{1}{2}$ percent. ${ }^{14}$ It is notable that, in the absence of controls for the reforms, the productivity coefficient is estimated at only 0.73 , biased by the downward level shift in real wages associated with the reforms, despite real wages and productivity moving in parallel before and after the Hartz reforms (Figure 4.1).

- In Spain, reforms of unemployment benefits

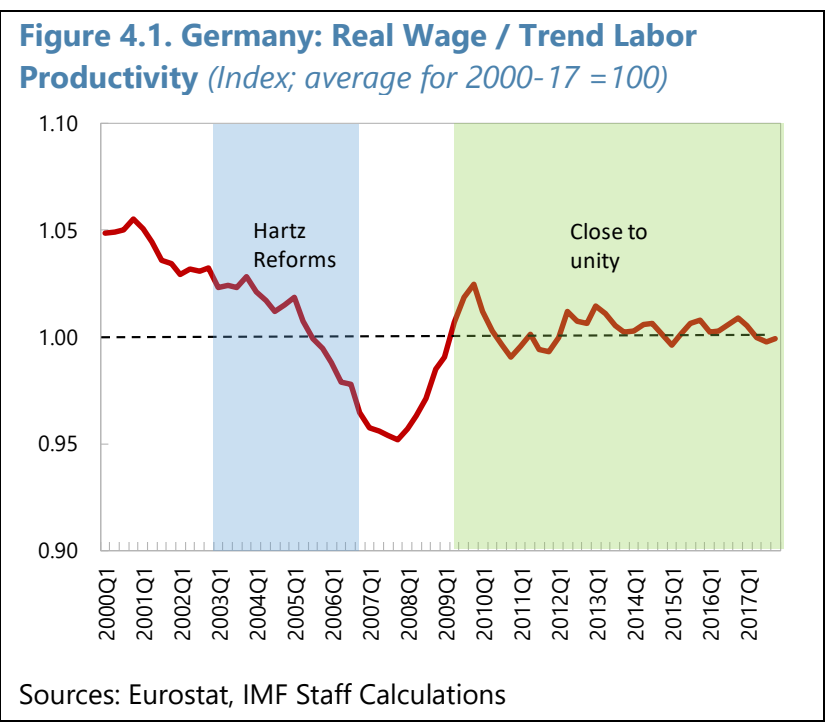
reduce real wages by estimated 4 percent. ${ }^{15}$ However, a dummy for such reforms has a counterintuitive sign in France as the timing of reform coincides with the aftermath of the global financial crisis when real product wages rose faster than productivity due to inertia in nominal wage growth.

- In Austria and the Netherlands, German wages also have a long-term impact with a coefficient of about 0.2 , consistent with their high trade connectedness with Germany. In the case of Austria, reforms of employment protection are found to reduce real wages by 3 percent.

\footnotetext{
${ }^{13}$ A Dickey-Fuller test rejects a unit root in the residuals of most country equations, consistent with a cointegrating relationship between real wages and productivity.

${ }^{14}$ Reforms to the German labor market from 2002 to 2005 as described in the technical appendix of Aiyar (2019). In practice, it may be difficult to disentangle the effects of the Hartz reforms from the effects of the opening up of Eastern Europe and global value chain integration.

${ }^{15}$ An employment protection reform dummy is also statistically significant for Spain, but it results in an implausibly high estimated parameter (about 1.5) on labor productivity. See IMF (2015) for a more comprehensive analysis of the impact of the 2012 labor market reforms.
} 
- In Belgium, besides German wages, French wages are also found to have a lasting effect on Belgium wages, consistent with its law of benchmarking domestic wage setting to foreign wages. ${ }^{16}$

\begin{tabular}{|c|c|c|c|c|c|c|}
\hline \multicolumn{7}{|c|}{ Table 4.1. Euro Area: Long-Run Equations for Real Product Wages ${ }^{17}$} \\
\hline VARIABLES & $\begin{array}{c}1) \\
\text { Germany }\end{array}$ & $\begin{array}{c}(2) \\
\text { France } \\
\end{array}$ & $\begin{array}{c}\text { (3) } \\
\text { Austria }\end{array}$ & $\begin{array}{c}(4) \\
\text { Belgium } \\
\end{array}$ & $\begin{array}{c}5) \\
\text { Spain } \\
\end{array}$ & $\begin{array}{c}(6) \\
\text { Netherlands } \\
\end{array}$ \\
\hline log trend productivity & $\begin{array}{c}1.027^{* * *} \\
(0.0328)\end{array}$ & $\begin{array}{c}0.932 * * * \\
(0.0193)\end{array}$ & $\begin{array}{c}0.789 * * * \\
(0.0300)\end{array}$ & $\begin{array}{c}0.437 * * * \\
(0.152)\end{array}$ & $\begin{array}{c}0.868 * * * \\
(0.0486)\end{array}$ & $\begin{array}{c}0.898 * * * \\
(0.0229)\end{array}$ \\
\hline log real German wage ${ }^{/ 1}$ & & & $\begin{array}{c}0.179 * * * \\
(0.0509)\end{array}$ & $\begin{array}{c}0.117^{*} \\
(0.0590)\end{array}$ & & $\begin{array}{c}0.262 * * * \\
(0.0353)\end{array}$ \\
\hline log real French wage ${ }^{1 /}$ & & & & $\begin{array}{c}0.494 * * * \\
(0.165)\end{array}$ & & \\
\hline Haartz reform dummy & $\begin{array}{c}-0.0546 * * * \\
(0.00541)\end{array}$ & & & & & \\
\hline Unemployment benefit reform dummy & & $\begin{array}{c}0.0319 * * * \\
(0.00272)\end{array}$ & & & $\begin{array}{c}-0.0389 * * * \\
(0.00561)\end{array}$ & \\
\hline Employment protection reform dummy & & & $\begin{array}{c}-0.0299 * * * \\
(0.00507)\end{array}$ & & & \\
\hline Constant & $\begin{array}{c}-5.996 * * * \\
(0.147)\end{array}$ & $\begin{array}{c}-5.537 * * * \\
(0.0874)\end{array}$ & $\begin{array}{c}-4.760 * * * \\
(0.178)\end{array}$ & $\begin{array}{c}-2.327^{* *} \\
(0.888)\end{array}$ & $\begin{array}{c}-5.688 * * * \\
(0.222)\end{array}$ & $\begin{array}{c}-4.964^{* * *} \\
(0.110)\end{array}$ \\
\hline Observations & 91 & 91 & 87 & 74 & 91 & 86 \\
\hline R-squared & 0.967 & 0.986 & 0.973 & 0.886 & 0.802 & 0.949 \\
\hline Dickey- Fuller Statistics & -2.661 & -2.648 & -3.880 & -1.720 & -2.843 & -3.660 \\
\hline $\begin{array}{l}\text { Standard errors in parentheses } \\
* * * p<0.01, * * p<0.05, * p<0.1 \\
1 \text { / deflated by GDP deflator in the count }\end{array}$ & of depende & t variable & & & & \\
\hline
\end{tabular}

In the newer EU members, productivity gains are generally translated into similar real wage rises over the long term (Table 4.2). In the Czech Republic, Estonia, Latvia, the Slovak Republic, and to a lesser extent Slovenia, the coefficient on labor productivity is close to unity. Poland and Hungary are outliers. In the case of Poland, the low coefficient appears to reflect real wage levels that are exceptionally high relative to productivity in the early years of the sample, a public-sector wage freeze after the crisis, and the surge in temporary foreign migrant workers in more recent years - the impact of which is not captured in official statistics. In Hungary, some data issues - including discontinuities in hours worked that affect both wages and productivity - may contribute to the very low coefficient estimate.

It is also found that foreign wage movements do not result in lasting deviations in real wages from trend productivity in the case of the new member states, as no long-run impact from foreign wages is found with trend productivity the key long-run driver. The trend

\footnotetext{
${ }^{16}$ Further information is provided in the IMF's 2017 Article IV Consultation for Belgium (IMF 2017c, Box 2). The estimated weights on foreign wages are sensitive to changing the dependent variable to wages and salaries (which exclude social security contributions by employers), with the estimated weights on French real wages lower at 0.194 and those on German wages higher at 0.163 .

${ }^{17}$ Estimated parameters on reform dummies may partly capture other factors as reform adoption is endogenous to labor market conditions, although the impact of cyclical factors should be limited in these long-run regressions.
} 
productivity paths of Austria, Belgium, and the Netherlands are broadly similar to Germany, so it is sustainable for real wages in those countries to be influenced by real wages in Germany. However, the NMS productivity trend is notably different to that of the EU15 countries given their convergence process from a much lower initial level of productivity. So, even though German wage developments are a starting point for annual wage negotiations in the NMS - as seen in the role of euro area wages in the short-run ECM equations--over the longer-term the higher productivity gains increase with ability and willingness of firms to pay, resulting in higher average real wage gains in the NMS.

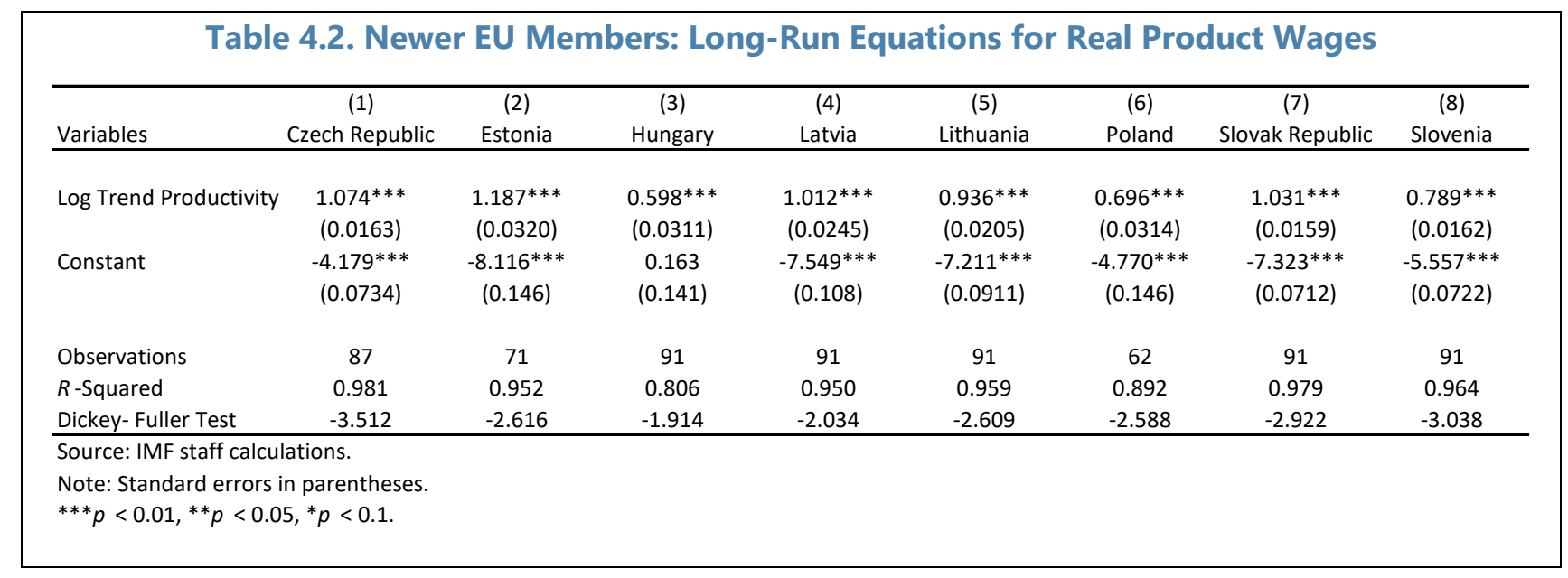

\section{B. Short run dynamics}

\section{Euro Area excl. Germany}

Panel regression results for this region are shown in Table 4.3.

Wage Phillips curve baseline: Column 1 shows estimates for the standard Phillips curve model, which confirms the literature that productivity growth, inflation and unemployment gaps (level and changes) are key nominal drivers of wage growth.

Broader unemployment indicators: Columns 2 and 3 progressively include broader slack indicators - nonemployment gap and hours gap, which are both statistically significant and marginally improve the model fit.

Error Correction analysis: Columns 4 to 6 are similar specifications except for including the fourth lag of the error correction terms. The coefficients on the error correction terms are highly significant and sizable at around -0.36 from the long-run regressions, implying on average about one-third of any deviation from long-term equilibrium is corrected in the following year. Their inclusion also improved the model fit significantly, suggesting that short-term wage growth dynamics are not only a function of current growth in the drivers, but also reflect convergence to the long run equilibrium.

External spillovers: The preferred specification (column 6) from the above is the error correction model using the nonemployment index gap rather than unemployment, with hours 
per employee as an additional slack indicator. ${ }^{18}$ Columns $7-10$ extend the preferred model by including spillovers from regional labor markets, which are found to have significant effects on wage growth in the Euro area countries. Changes in euro area unemployment (lagged two quarters) and the growth rate in euro area wages (lagged three quarters) are both statistically significant (columns 7 and 8). ${ }^{19}$

Migration: Increases in net migration inflows are found to weigh on subsequent wage growth, but the impact is modest and temporary. Controlling for domestic slack and regional developments, a rise in net migrant inflows by 1 percentage point of the labor force - which is an exceptionally large shock - is found to reduce wage growth in the following year by 0.4 percent (column 9). But in practice, changes in net migration flows are generally small relative to the labor force, so the wage effects are also small. These effects are also temporary, as they reflect the change in migration flows rather than the level, and wages also converge back to long-term equilibrium over time. Interestingly, when migration is separated into inflows and outflows (column 10), the latter have a larger coefficient, although the difference is not statistically significant. Nonetheless, it suggests that at least in the near term, migrants to a country are not perfect substitutes for the domestic workforce.

\section{Newer EU Members}

Wage Phillips curve baseline: As shown in Table 4.4, the wage Phillips curves again have sensible properties, with sizable effects from trend productivity growth, expected inflation, and labor market slack. Unlike the euro area countries, lagged inflation is not statistically significant, reducing the nominal inertia in the wages in newer EU members.

Broader unemployment indicators: It is also notable that the coefficients on the labor market slack are notably higher in the new member states, indicating greater wage flexibility, which aids adjustment to asymmetric shocks. ${ }^{20}$

Error correction analysis: In addition, the pace of wage convergence to the equilibrium is also slightly higher in the new member states, with the coefficient on the error correction term at -0.40 . The error correction model with the nonemployment index gap also provides a larger increase in explanatory power relative to unemployment in newer member states. ${ }^{21}$

\footnotetext{
${ }^{18}$ For the euro area excluding Germany, estimation of a six-country panel including Italy gave similar results to those in Table 4.3 column 8 , but hours per person are not significant and the mix of spillovers differs, with a larger coefficient on euro area wage growth and a smaller and insignificant coefficient on changes in euro area unemployment. But, as noted above, the long-term parameter estimates for Italy may be less reliable given the near absence of productivity growth since 2002 in Italy.

${ }^{19}$ For the smaller euro area economies, there are also spillovers through the role of foreign wages in the longrun equation via the error correction model term.

${ }^{20}$ Panel regressions that replace the nonemployment index gap with both unemployment and changes in involuntary part-time employment, while retaining the hours gap, yield similar results.

${ }^{21}$ Although the parameter on trend labor productivity growth tends to be lower in the error correction model, productivity also affects wages through the error correction model term, and in the long run the impact of productivity on real wages is higher in the error correction model.
} 
External spillovers: Spillovers from foreign labor markets are found to have more significant effects on wage growth in the newer member states. Changes in unemployment in the euro area (columns 8 and 9) have substantial and significant impacts on wage growth, with short lags, suggesting that wages need to respond quickly to improving job opportunities in euro area countries to help retain workers. The growth in euro area wages also has a significant impact (column 9), consistent with anecdotal reports that they are the starting point for wage bargaining in many newer member states.

Migration: The effect of migrant flows on wage growth is similar for both regions, with the effect modest and temporary. A rise in inflows by 1 percentage point-which is an exceptionally large shock - is found to reduce wage growth in the following year by 0.5 percent in the newer EU members, compared with 0.4 percent in the other euro area countries.

\section{Germany}

Wage Phillips curve baseline: For Germany, the wage Phillips curve again has sensible properties, with quite high responsiveness to the unemployment gap, trend productivity, and inflation expectations.

Broader unemployment indicators: The growth in involuntary part-time employment proved to be a key indicator of slack (Table 4.5). A nonemployment index was also significant, but the coefficient on the growth rate in labor productivity became negative. Given the longer sample available for Germany, changes in involuntary part-time employment were included separately, with the sizable coefficient perhaps reflecting the more widespread use of changes in employee hours to avoid layoffs.

Error Correction analysis: The error correction term is particularly high (about -0.6$)$ and it contributes substantially to explanatory power, making the error correction model with the changes in involuntary employment the best baseline model (column 6).

External spillovers: German wage setting appears to be anchored on domestic labor market conditions and less sensitive to spillovers than either of the regional panels. German wages are not found to be responsive to changes in euro area unemployment (column 7 in Table 4.5), while the estimated coefficient on euro area wage growth has the opposite sign (column 8) from that expected from a spillover.

Migration: Changes in net migration flows also do not have a statistically significant impact on German wages (column 9). 


\section{Factors Driving Wage Growth}

\section{A. Decomposition}

\section{Euro Area excl. Germany}

Wage moderation in the aftermath of global financial crisis can be attributed to a combination of factors (Figure 5.1). The initial slowing in wage rises (average from the five-country panel) by 2.3 percentage points (ppts) in 2010 is linked to lower inflation expectations ( $0.8 \mathrm{ppts})$, lower past inflation ( $0.5 \mathrm{ppts})$, domestic labor slack ( $0.6 \mathrm{ppts})$, and wage overhang captured by the error correction term $(0.3 \mathrm{ppts})$. The error correction continued to weigh on wages by 0.2 to 0.3 ppts during $2011-15$, helping account for wage moderation in that period. During 2011-13, inflation expectations and actual inflation recovered, lifting their combined contribution to wage growth by 0.9 ppts. But the euro area crisis meant that domestic and external slack began to weigh more heavily on wages during 2012-14, with a total drag of 0.6 ppts on wage growth in both 2013 and 2014. This drag was amplified by the contributions from inflation expectations and inflation falling sharply during 2014-15 by 0.9 ppts, with only a slight increase seen by 2017 .

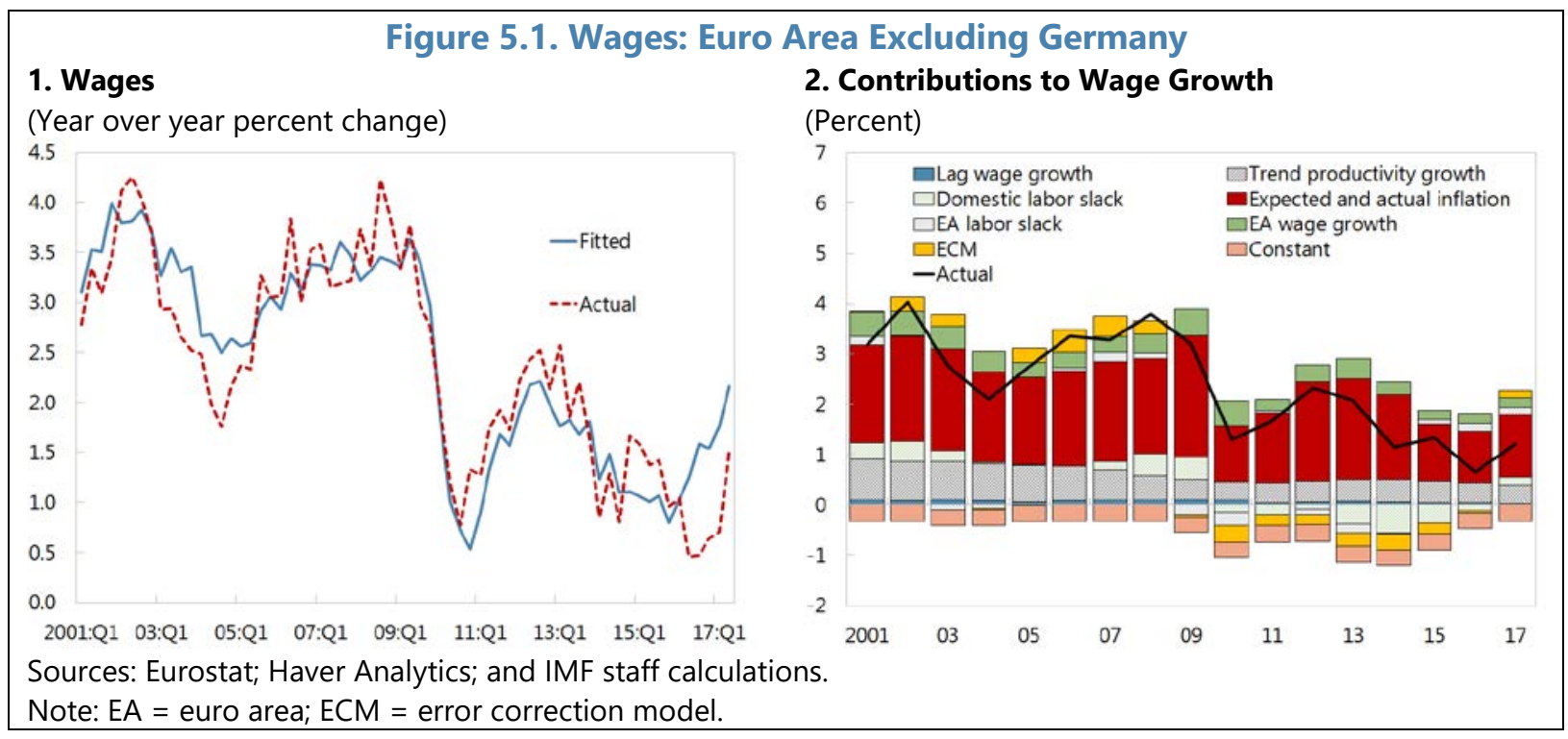

\section{Newer EU Members}

In the newer member states, declines in both domestic and foreign slack have contributed to wages picking up in recent years, based on average results from the eight-country panel (Figure 5.2). The sharp halt in wage rises in 2009 reflected large negative contributions from both rising domestic slack and rising euro area unemployment, plus some error correction drag as trend productivity declined. Even as the high level of domestic and external slack continued to drag on wage rises during 2010-14, by 2011 the declines in domestic slack began to support wages, while declines in euro area unemployment began to support wages beginning in 2014. By 2016-17, the low level of domestic slack began to reinforce wage rises. Yet this combination of domestic and external pressures does not fully account for the 
extent of wage acceleration during 2016-17, which may be partly due to migration outflows. However, data on migration in recent years are not yet available.

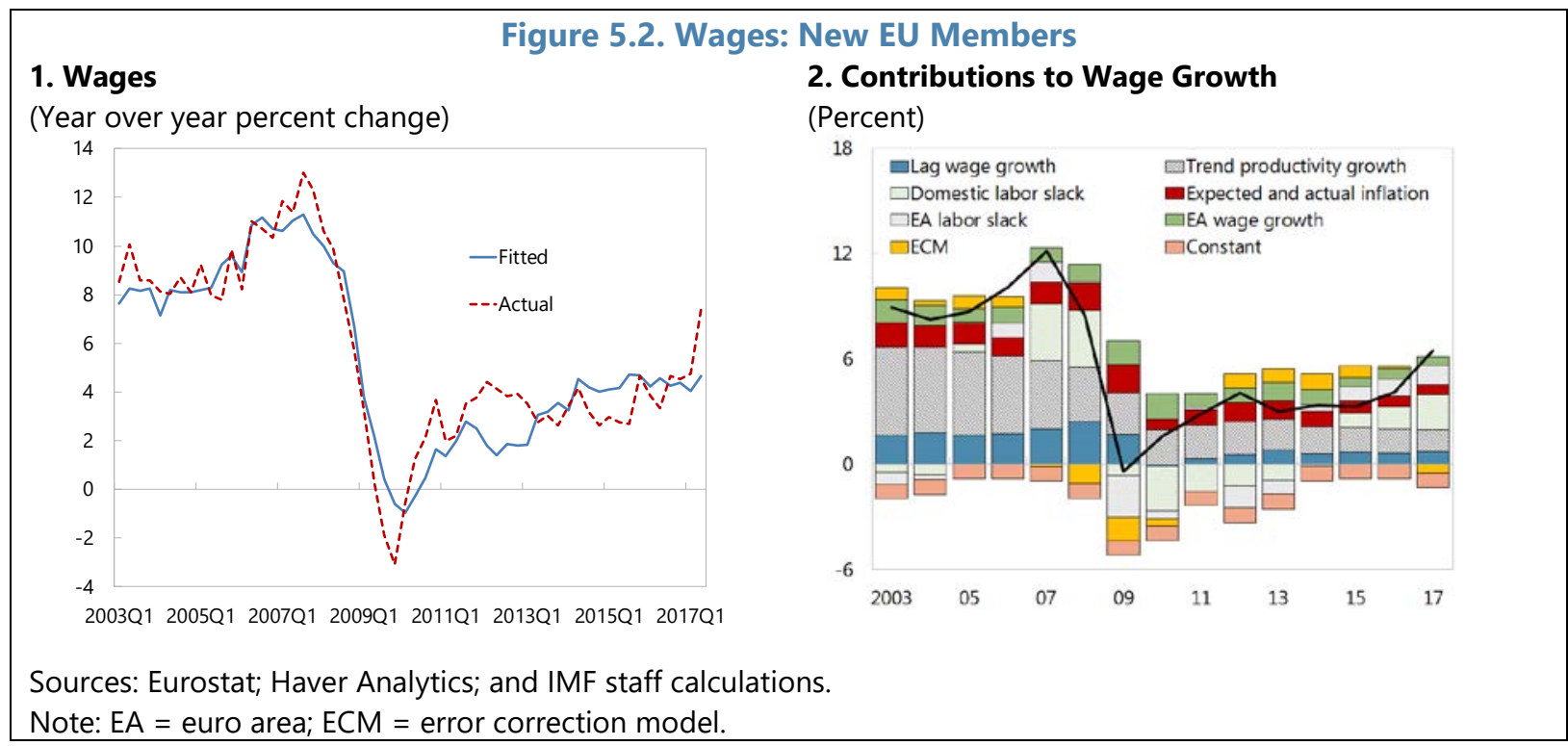

\section{Germany}

Domestic labor market conditions and inflation expectations have been key factors behind variations in nominal wage growth (Figure 5.3). The steep initial fall in wage growth by 2.9 percentage points in 2010 is linked to lower inflation expectations ( 0.9 ppts), domestic labor slack ( $0.3 \mathrm{ppts})$, and the error correction (1 ppt). Domestic slack also weighed on wages in 2011 and has not become a source of upward wage pressure in more recent years. During 2011-13, inflation expectations recovered, lifting the contribution of those expectations to wage growth by 0.8 ppts. Wage growth higher than 3 percent in 2012, despite low inflation and productivity growth, led to a significant error correction drag on wages during 2012-14, peaking at 0.7 ppts in 2013. This drag was amplified by the contributions from inflation expectations falling during 2014-15 by 0.4 ppts, with a slight additional decline in 2017 .

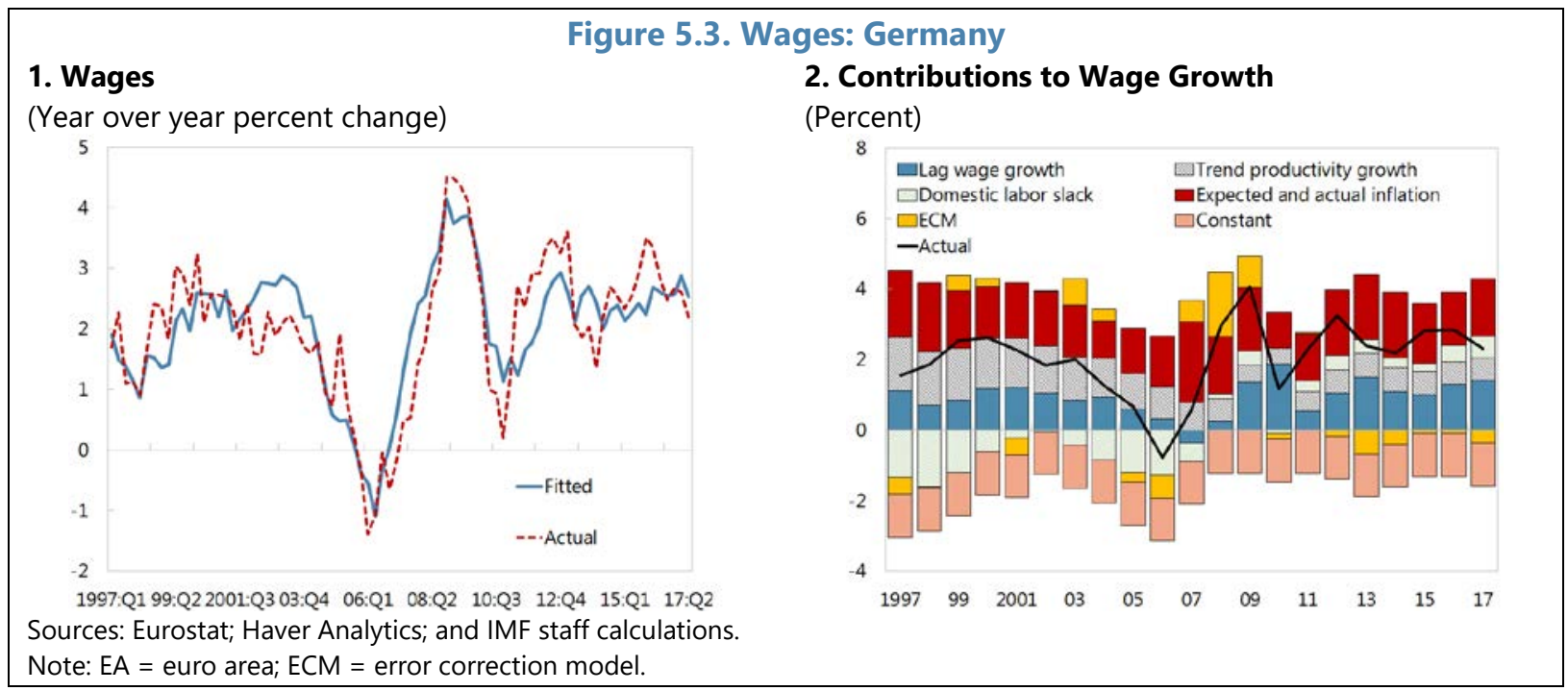




\section{B. Regional Differences in Wage Growth}

In newer EU members, greater wage sensitivity to domestic labor market slack and to external developments help account for the faster wage increases in these countries (Figure 5.4). Wages are found to be more responsive to domestic labor slack in the newer members, with the coefficients on the nonemployment gap and hours gap about two times larger (column 8), and the impact of changes in nonemployment is much larger in the newer members than in the EU15, so wages also respond more rapidly to changes in slack. Hence, in the wake of the global financial crisis, the adverse impact of domestic slack on newer member state wage growth was much larger than in the euro area excluding Germany.

In more recent years, domestic slack has diminished more rapidly in the newer member states, with an estimated contribution to wage growth of about 2 percentage points. In addition, wage dynamics in the newer members are also found to be more sensitive to external labor market developments, with combined spillovers from euro area unemployment and euro area wage rises accounting for about $1 \frac{1}{2}$ percentage points of the wage pickup in the newer members, compared with less than $1 / 2$ percentage point in the euro area excluding Germany during 2015-17.

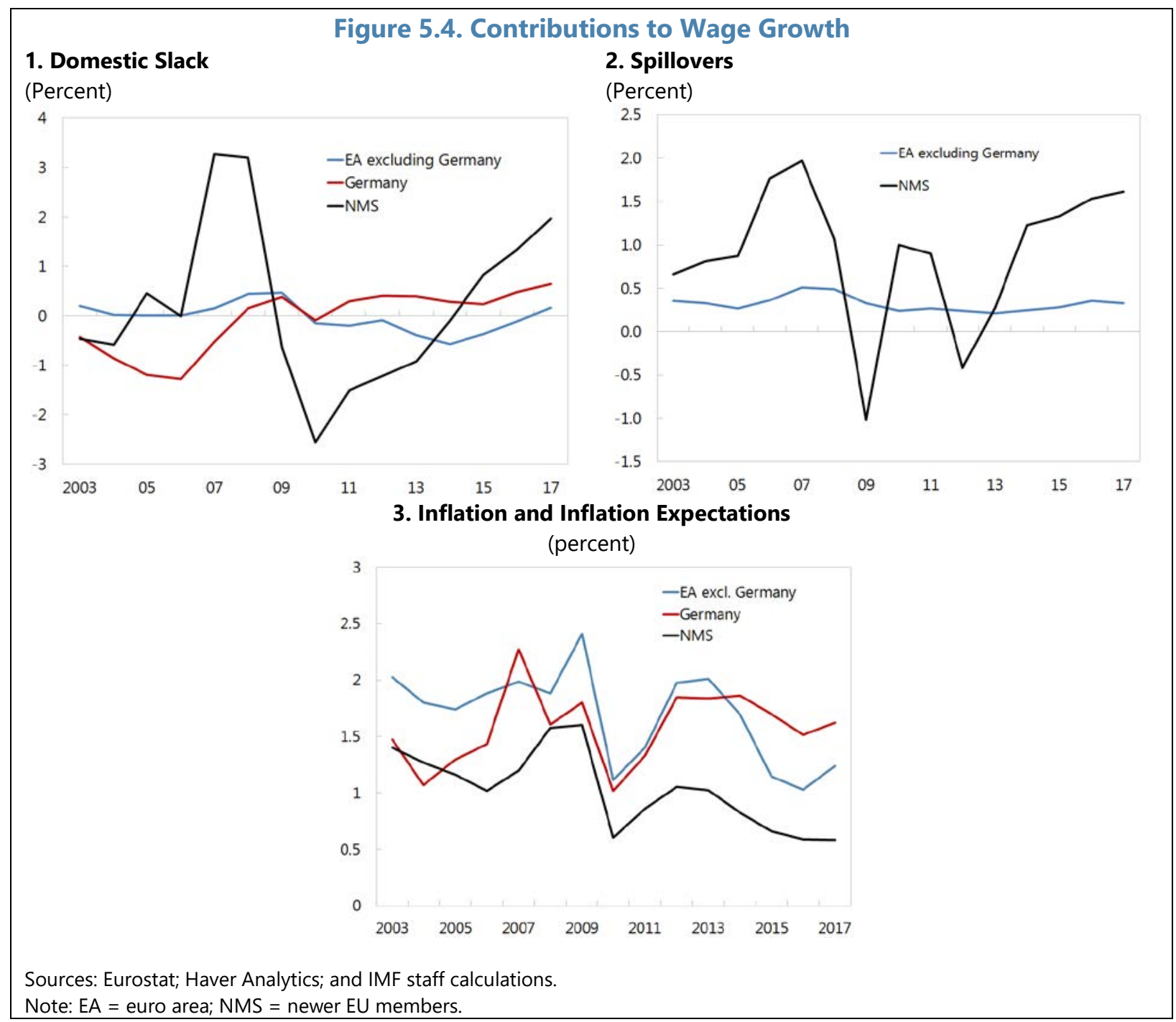


In the euro area, subdued inflation has been a key factor weighing on wage rises in recent years (Figure 5.4). Compared with the new EU members, expected and lagged inflation are much more important factors driving wage formation in the EU15, with the coefficient on lagged inflation much more significant and the contribution from expected inflation more than two times higher in the EU15 than in the newer member states. Despite some recent increases in actual inflation, near-term expected inflation in the euro area remains subdued. Thus, the overall contribution of inflation expectations to wage increases declined by half a percentage point during 2016-17 compared with 2012-13. Overall, the persistence in inflation, and hence in inflation expectations, also contributes to the persistence of subdued wage rises. ${ }^{22}$ Moreover, subdued wage rises, which shape growth in nominal incomes and spending, could themselves be a contributor to persistently low inflation.

\section{Simulation of Spillovers}

The scale and nature of spillovers can be illustrated through a scenario analysis of a rise in German wage growth (Figure 5.5). For illustrative purposes, hourly wage rates in Germany are assumed to rise 1 percentage point faster than in a baseline, which would raise euro area wage growth by about 0.4 percentage point given Germany's weight in the euro area. This would spill over into the growth of wages in both regional panels. Moreover, higher German wages also spill over through the long-run equations for Austria, Belgium, and the Netherlands. Overall, wage growth in the euro area excluding Germany rises about 0.1 percent after one year and 0.2 percent in the medium term. The impact on newer EU member country wages is slightly larger in the near term (about 0.15 percent after one year), but fades to zero over time because in the long run real wages in the newer member states depend only on domestic labor productivity. To the extent that higher wages lead to higher inflation, through either domestic demand or cost channels, the mediumterm impact on wages would be higher than these simulations indicate.

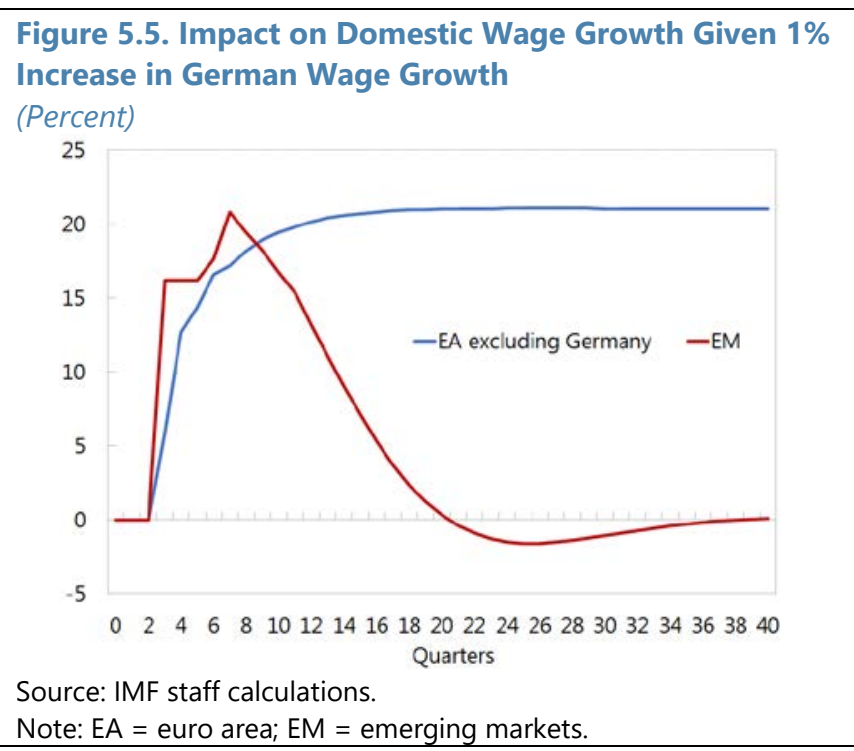

\section{Wage Outlook}

With labor market slack continuing to diminish and inflation rising, wage growth is expected to accelerate to just below 4 percent in Germany, 3.5 percent on average in other Euro area countries, and just below 6 percent in new EU members by the end-2021 (Figure 5.6). Trend productivity growth is assumed to remain at the current level. A more optimistic outlook for productivity recovery would imply faster wage growth.

\footnotetext{
${ }^{22}$ For analysis on inflation persistence, see Abdin et al. 2018.
} 
The projections are subject to various uncertainties. On the downside, the extent to which the labor market condition can improve further depends on the share of unemployment and under-employment that is structural. The literature seems to suggest that post-crisis structural unemployment is likely to be higher than before the crisis, limiting the room for further improvement of labor market condition, and recovery of wage growth. In addition, the sensitivity of wages to fundamentals can also vary over time. For instance, with higher integration of product and labor markets (IMF 2017b, Feenstra and Hanson 1997; Grossman and Rossi-Hansberg 2008) across the EU countries, domestic fundamentals may have less effect on wage growth, while foreign factors such as foreign wages and slack in the foreign labor market become more important (e.g. Zhang 2017). In this case, the wage development in wage-leaders such as Germany becomes a key leading indicators of wage growth for the rest of the region.

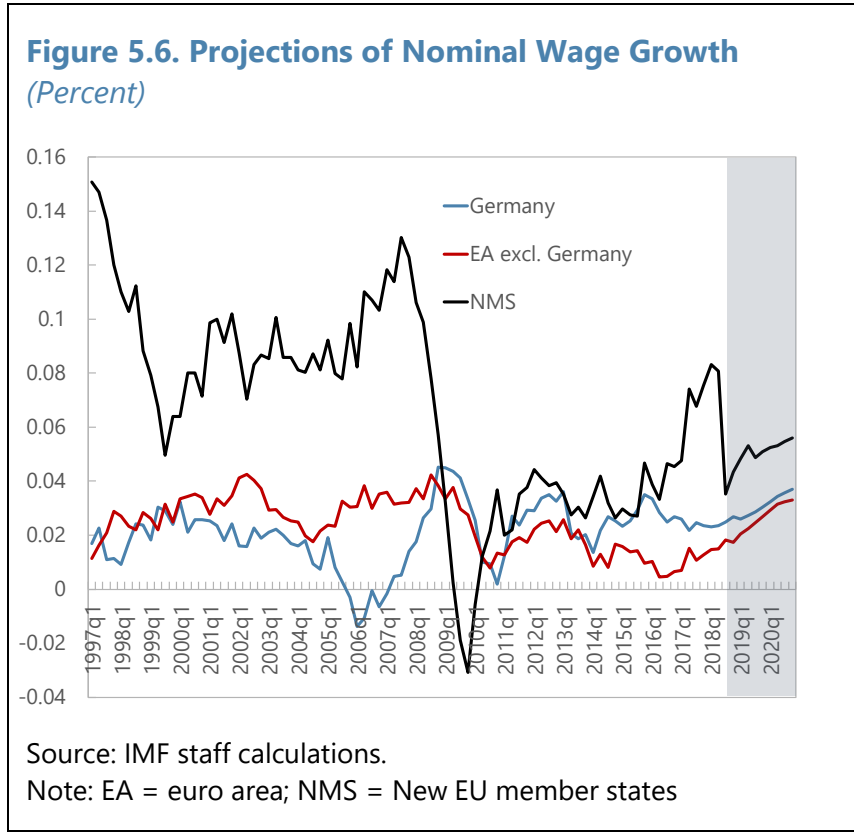

\section{Conclusions}

To summarize, wage developments in the EU15 and newer EU members are both linked to labor productivity in the long-run, but the responsiveness of wage growth to drivers differs across these two regions. In the EU15, wages respond relatively slowly to changes in unemployment and are closely related to inflation and inflation expectations for the coming year. Viewed against this evidence, current nominal wage developments are not unusual, rather, short-term inflation expectations are unusually low owing to prolonged low inflation.

By contrast, in the newer EU members, the econometric evidence suggests that wage growth responds more quickly to changes in labor market slack. This, together with the lower importance of inflation and short-term inflation expectations, explains why wage growth in these countries is accelerating faster and sooner.

In addition, although real wages largely follow labor productivity in the long run, deviations from that equilibrium can develop over time. Incorporating such deviations into the analysis, using the error correction model, facilitates the understanding of wage moderation, especially in the wake of major shocks to regions with nominal wage inertia, such as the EU15. In particular, during the global financial crisis, nominal wage rises in the EU15 declined little at first even as inflation and productivity growth fell notably, resulting in a rise in real wages relative to labor productivity trends. The low nominal wage growth for some years after the crisis in part reflected an unwinding of that gap or real wage overhang.

Moreover, while unemployment remains the main indicator of labor market slack, broader indicators can be useful complementary indicators of slack that contain additional 
information for future wage growth. In particular, both involuntary part-time employment and hours worked per person were found to have supplementary information to unemployment on overall slack in the labor market. Moreover, a nonemployment index that incorporates involuntary part-time employment along with marginally attached workers is found to increase the explanatory power for wage developments relative to unemployment.

Another noteworthy finding is that cross-country labor market spillovers through labor market conditions, wage competition and migrant flows also influence wage growth. For the EU15, labor market slack in foreign countries and slow wage growth among trade competitors contributed to the recent wage moderation, on top of the remaining domestic labor slack and subdued inflation. For the newer EU members, spillover effects are also significant, but not sufficient to outweigh the positive effect on wages from domestic labor market recovery. 


\section{REFERENCES}

Abdih, Yasser, Lin Li, and Anne-Charlotte Paret, 2018, "Understanding Euro Area Inflation Dynamics: Why So Low for So Long?” IMF Working Paper.

Aiyar, Shekhar, et al, 2019, "Strengthening the Euro Area: The Role of National Structural Reforms in Enhancing Resilience," IMF Staff Discussion Note.

Bell, David and David Blanchflower. 2018, "Underemployment in the US and Europe," Industrial and Labor Relations Review, forthcoming, previously NBER Working Paper. No. 24927.

Blanchard, Olivier and Lawrence Katz, 1999, "Wage Dynamics: Reconciling Theory and Evidence," American Economic Review 89 (2): 69-74.

Bulligan, Guido, Elisa Guglielminetti, and Eliana Viviano, 2017, "Wage Growth in the Euro Area: Where Do We Stand?” Banca d'Italia Occasional Paper 413, Rome.

Chen, Jiaqian, 2018, “United Kingdom: Selected Issues,” IMF Country Report 18/43, Washington, D.C.

Feenstra, Robert, and Gordon Hanson, 1997, "Foreign Direct Investment and Relative Wages: Evidence from Mexico's Maquiladoras," Journal of International Economics, 42 (3-4): 371-93.

Grossman, Gene, and Esteban Rossi-Hansberg, 2008, “Trading Tasks: A Simple Theory of Offshoring," American Economic Review, 98 (5): 1978-97.

International Monetary Fund (IMF), 2016, "Emigration and Its Economic Impact on Eastern Europe,” IMF Staff Discussion Note 16/07, Washington, D.C.

, 2017a, "Chapter 2: Recent Wage Dynamics in Advanced Economies: Drivers and Implications," World Economic Outlook, October 2017, Washington, D.C.

,2017b, "Labor and Product Market Reforms in Advanced Economies: Fiscal Costs, Gains, and Support,” IMF Staff Discussion Note 17/03, Washington, D.C.

D.C. , 2017c, "Belgium: 2017 Article IV Consultation Staff Report,” Washington,

, 2018, "Chapter 2: European Wage Dynamics and Labor Market Integration," Regional Economic Outlook: Europe, May 2018, Washington, D.C.

Kangur, Alvar, 2018, "Competitiveness and Wage Bargaining Reform in Italy," IMF Working Paper 18/61, International Monetary Fund, Washington, D.C. 
Zhang, Yuanyan, 2017, "Recent Wage Moderation in Sweden,” IMF Country Report 17/351, Washington, D.C.

Zhang, Yuanyan, 2018, "Wage Moderation in the Netherlands," IMF Country Report 18/131, Washington, D.C. 


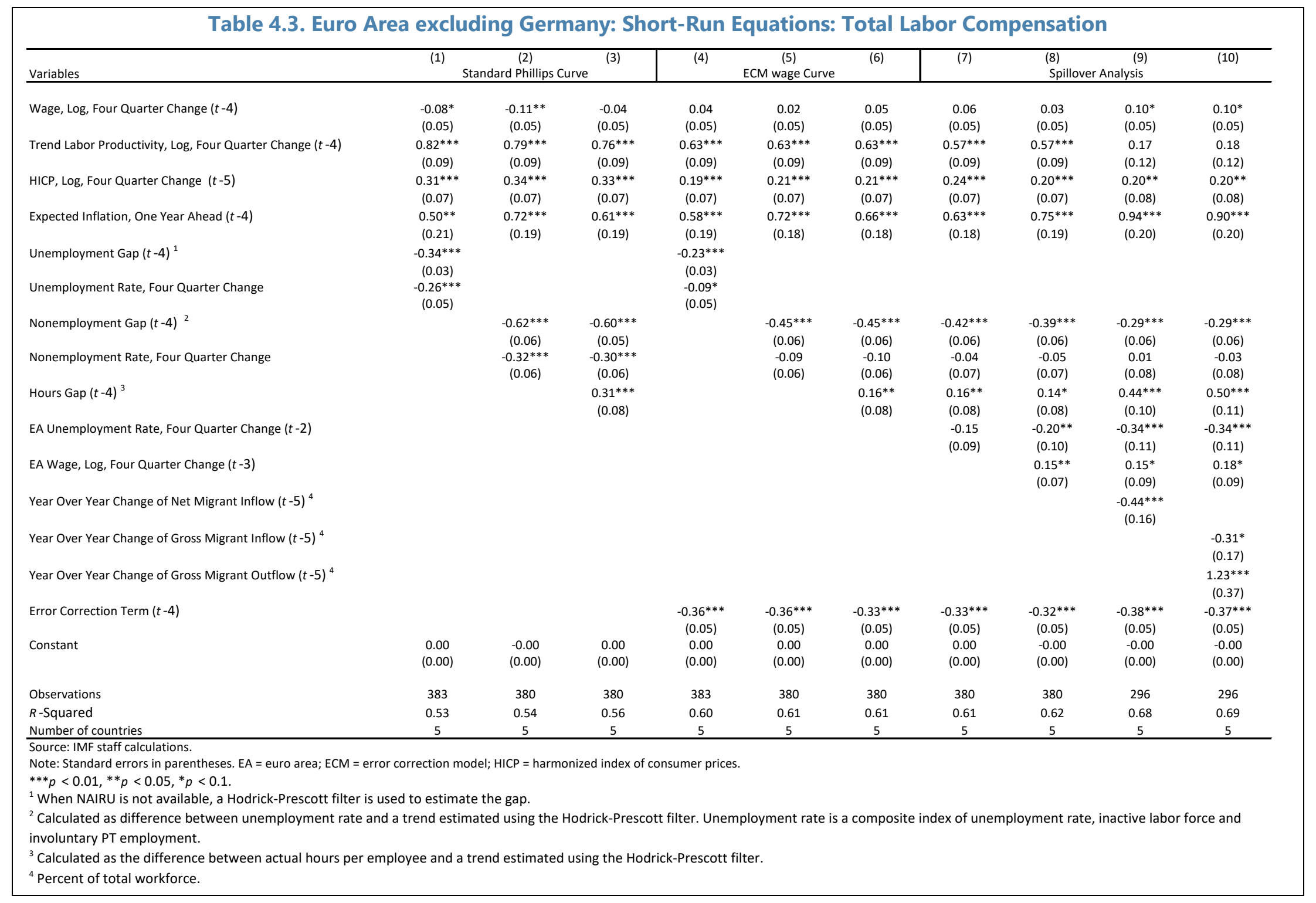




\begin{tabular}{|c|c|c|c|c|c|c|c|c|c|c|}
\hline \multirow{2}{*}{$\begin{array}{l}\text { Variables } \\
\text { Wage, Log, Four Quarter Change }(t-4)\end{array}$} & \multicolumn{3}{|c|}{$\begin{array}{ll}\text { (1) } & (2) \\
& \text { Standard Phillips Curve } \\
\end{array}$} & (4) & $\begin{array}{c}\text { (5) } \\
\text { ECM Wage Curve }\end{array}$ & (6) & (7) & \multicolumn{2}{|c|}{$\begin{array}{lr}(8) & (9) \\
\text { Spillover Analysis } \\
\end{array}$} & (10) \\
\hline & $\begin{array}{c}0.02 \\
(0.05)\end{array}$ & $\begin{array}{l}-0.05 \\
(0.05)\end{array}$ & $\begin{array}{l}0.00 \\
(0.05)\end{array}$ & $\begin{array}{c}0.19^{* * *} \\
(0.05)\end{array}$ & $\begin{array}{l}0.11^{* *} \\
(0.05)\end{array}$ & $\begin{array}{c}0.16^{* * *} \\
(0.05)\end{array}$ & $\begin{array}{c}0.20^{* * *} \\
(0.05)\end{array}$ & $\begin{array}{c}0.20^{* * *} \\
(0.05)\end{array}$ & $\begin{array}{c}0.23^{* * *} \\
(0.05)\end{array}$ & $\begin{array}{c}0.23^{* * *} \\
(0.05)\end{array}$ \\
\hline Trend Labor Productivity, Log, Four Quarter Change $(t-4)$ & $\begin{array}{c}1.20^{* * *} \\
(0.12)\end{array}$ & $\begin{array}{c}1.21^{* * *} \\
(0.12)\end{array}$ & $\begin{array}{c}1.18^{* * *} \\
(0.11)\end{array}$ & $\begin{array}{c}1.05^{* * *} \\
(0.11)\end{array}$ & $\begin{array}{c}1.08^{* * *} \\
(0.11)\end{array}$ & $\begin{array}{c}1.05^{* * *} \\
(0.11)\end{array}$ & $\begin{array}{c}1.03^{* * *} \\
(0.10)\end{array}$ & $\begin{array}{c}0.95 * * * \\
(0.11)\end{array}$ & $\begin{array}{c}0.96^{* * *} \\
(0.12)\end{array}$ & $\begin{array}{c}0.96^{* * *} \\
(0.12)\end{array}$ \\
\hline HICP, Log, Four Quarter Change $(t-5)$ & $\begin{array}{l}0.13 \\
(0.09)\end{array}$ & $\begin{array}{l}0.16^{*} \\
(0.09)\end{array}$ & $\begin{array}{c}0.10 \\
(0.09)\end{array}$ & $\begin{array}{l}-0.07 \\
(0.09)\end{array}$ & $\begin{array}{l}-0.02 \\
(0.09)\end{array}$ & $\begin{array}{l}-0.07 \\
(0.09)\end{array}$ & $\begin{array}{c}0.03 \\
(0.09)\end{array}$ & $\begin{array}{l}0.03 \\
(0.09)\end{array}$ & $\begin{array}{l}-0.00 \\
(0.09)\end{array}$ & $\begin{array}{l}-0.00 \\
(0.09)\end{array}$ \\
\hline Expected Inflation, One Year Ahead $(t-4)$ & $\begin{array}{c}0.63 * * * \\
(0.14)\end{array}$ & $\begin{array}{c}0.58^{* * *} \\
(0.14)\end{array}$ & $\begin{array}{c}0.58^{* * *} \\
(0.14)\end{array}$ & $\begin{array}{c}0.59 * * * \\
(0.13)\end{array}$ & $\begin{array}{c}0.54^{* * *} \\
(0.13)\end{array}$ & $\begin{array}{c}0.54^{* * *} \\
(0.13)\end{array}$ & $\begin{array}{l}0.31^{* *} \\
(0.13)\end{array}$ & $\begin{array}{c}0.34^{* *} \\
(0.13)\end{array}$ & $\begin{array}{c}0.38^{* *} \\
(0.15)\end{array}$ & $\begin{array}{c}0.38^{* * *} \\
(0.15)\end{array}$ \\
\hline Unemployment Gap $(t-4)^{1}$ & $\begin{array}{c}-0.79 * * * \\
(0.09)\end{array}$ & & & $\begin{array}{c}-0.63^{* * *} \\
(0.08)\end{array}$ & & & & & & \\
\hline Unemployment Rate, Four Quarter Change & $\begin{array}{c}-1.41^{* * *} \\
(0.10)\end{array}$ & & & $\begin{array}{c}-0.89 * * * \\
(0.11)\end{array}$ & & & & & & \\
\hline Nonemployment Gap $(t-4)^{2}$ & & $\begin{array}{c}-1.27 * * * \\
(0.12)\end{array}$ & $\begin{array}{c}-1.13 * * * \\
(0.13)\end{array}$ & & $\begin{array}{c}-1.09 * * * \\
(0.12)\end{array}$ & $\begin{array}{c}-0.97^{* * *} \\
(0.12)\end{array}$ & $\begin{array}{c}-0.84^{* * *} \\
(0.12)\end{array}$ & $\begin{array}{c}-0.86^{* * *} \\
(0.12)\end{array}$ & $\begin{array}{c}-0.82^{* * *} \\
(0.13)\end{array}$ & $\begin{array}{c}-0.82^{* * *} \\
(0.13)\end{array}$ \\
\hline Nonemployment Rate, Four Quarter Change & & $\begin{array}{l}-2.04 * * * \\
(0.13)\end{array}$ & $\begin{array}{c}-1.98^{* * *} \\
(0.13)\end{array}$ & & $\begin{array}{c}-1.36 * * * \\
(0.14)\end{array}$ & $\begin{array}{c}-1.31^{* * *} \\
(0.14)\end{array}$ & $\begin{array}{c}-0.99^{* * *} \\
(0.15)\end{array}$ & $\begin{array}{c}-1.06 * * * \\
(0.16)\end{array}$ & $\begin{array}{c}-1.06^{* * *} \\
(0.17)\end{array}$ & $\begin{array}{c}-1.06 * * * \\
(0.17)\end{array}$ \\
\hline Hours Gap $(t-4)^{3}$ & & & $\begin{array}{c}0.31^{* * *} \\
(0.10)\end{array}$ & & & $\begin{array}{c}0.29 * * * \\
(0.09)\end{array}$ & $\begin{array}{c}0.29 * * * \\
(0.09)\end{array}$ & $\begin{array}{c}0.28^{* * *} \\
(0.09)\end{array}$ & $\begin{array}{c}0.26 * * * \\
(0.09)\end{array}$ & $\begin{array}{c}0.26 * * * \\
(0.09)\end{array}$ \\
\hline EA Unemployment Rate, Four Quarter Change $(t-2)$ & & & & & & & $\begin{array}{c}-1.21 * * * \\
(0.26)\end{array}$ & $\begin{array}{c}-1.36^{* * *} \\
(0.27)\end{array}$ & $\begin{array}{c}-1.22^{* * *} \\
(0.30)\end{array}$ & $\begin{array}{c}-1.22^{* * *} \\
(0.30)\end{array}$ \\
\hline EA Wage, Log, Four Quarter Change $(t-3)$ & & & & & & & & $\begin{array}{l}0.41^{*} \\
(0.22)\end{array}$ & $\begin{array}{l}0.40^{*} \\
(0.24)\end{array}$ & $\begin{array}{l}0.40^{*} \\
(0.25)\end{array}$ \\
\hline Year Over Year Change of Net Migrant Inflow $(t-5)^{4}$ & & & & & & & & & $\begin{array}{l}-0.52^{*} \\
(0.28)\end{array}$ & \\
\hline Year Over Year Change of Gross Migrant Inflow $(t-5)^{4}$ & & & & & & & & & & $\begin{array}{l}-0.36 \\
(0.54)\end{array}$ \\
\hline Year Over Year Change of Gross Migrant Outflow $(t-5)^{4}$ & & & & & & & & & & $\begin{array}{l}0.58^{*} \\
(0.32)\end{array}$ \\
\hline Error Correction Term $(t-4)$ & & & & $\begin{array}{c}-0.40^{* * *} \\
(0.04)\end{array}$ & $\begin{array}{c}-0.40^{* * *} \\
(0.04)\end{array}$ & $\begin{array}{c}-0.40^{* * *} \\
(0.04)\end{array}$ & $\begin{array}{c}-0.44^{* * *} \\
(0.04)\end{array}$ & $\begin{array}{c}-0.44^{* * *} \\
(0.04)\end{array}$ & $\begin{array}{c}-0.45^{* * *} \\
(0.04)\end{array}$ & $\begin{array}{c}-0.45^{* * *} \\
(0.04)\end{array}$ \\
\hline Constant & $\begin{array}{l}-0.00 \\
(0.00)\end{array}$ & $\begin{array}{c}-0.00 \\
(0.00)\end{array}$ & $\begin{array}{l}-0.00 \\
(0.00)\end{array}$ & $\begin{array}{l}-0.00 \\
(0.00)\end{array}$ & $\begin{array}{l}-0.00 \\
(0.00)\end{array}$ & $\begin{array}{l}-0.00 \\
(0.00)\end{array}$ & $\begin{array}{l}-0.00 \\
(0.00)\end{array}$ & $\begin{array}{l}-0.01 \\
(0.01)\end{array}$ & $\begin{array}{l}-0.01^{*} \\
(0.01)\end{array}$ & $\begin{array}{l}-0.01^{*} \\
(0.01)\end{array}$ \\
\hline Observations & 576 & 568 & 568 & 576 & 568 & 568 & 568 & 568 & 516 & 516 \\
\hline$R$-Squared & 0.52 & 0.55 & 0.56 & 0.58 & 0.62 & 0.62 & 0.64 & 0.64 & 0.65 & 0.65 \\
\hline Number of countries & 8 & 8 & 8 & 8 & 8 & 8 & 8 & 8 & 8 & 8 \\
\hline $\begin{array}{l}\text { Source: IMF staff calculations. } \\
\text { Note: Standard errors in parentheses. EA = euro area; ECM } \\
{ }^{* * *} p<0.01,{ }^{* *} p<0.05,{ }^{*} p<0.1 . \\
{ }^{1} \text { When NAIRU is not available, a Hodrick-Prescott filt } \\
{ }^{2} \text { Calculated as difference between unemployment ra } \\
\text { involuntary PT employment. } \\
{ }^{3} \text { Calculated as the difference between actual hours } p \\
{ }^{4} \text { Percent of total workforce. }\end{array}$ & $\begin{array}{l}\text { model; HIC } \\
\text { imate the } \\
\text { stimated } 4 \\
\text { d a trend } \mathrm{C}\end{array}$ & harmonizec & ex of consu & $\begin{array}{l}\text { ices. } \\
\text { tt filter. }\end{array}$ & nt rate is a co & site ind & inemplo & rate, ina & bor fo & \\
\hline
\end{tabular}




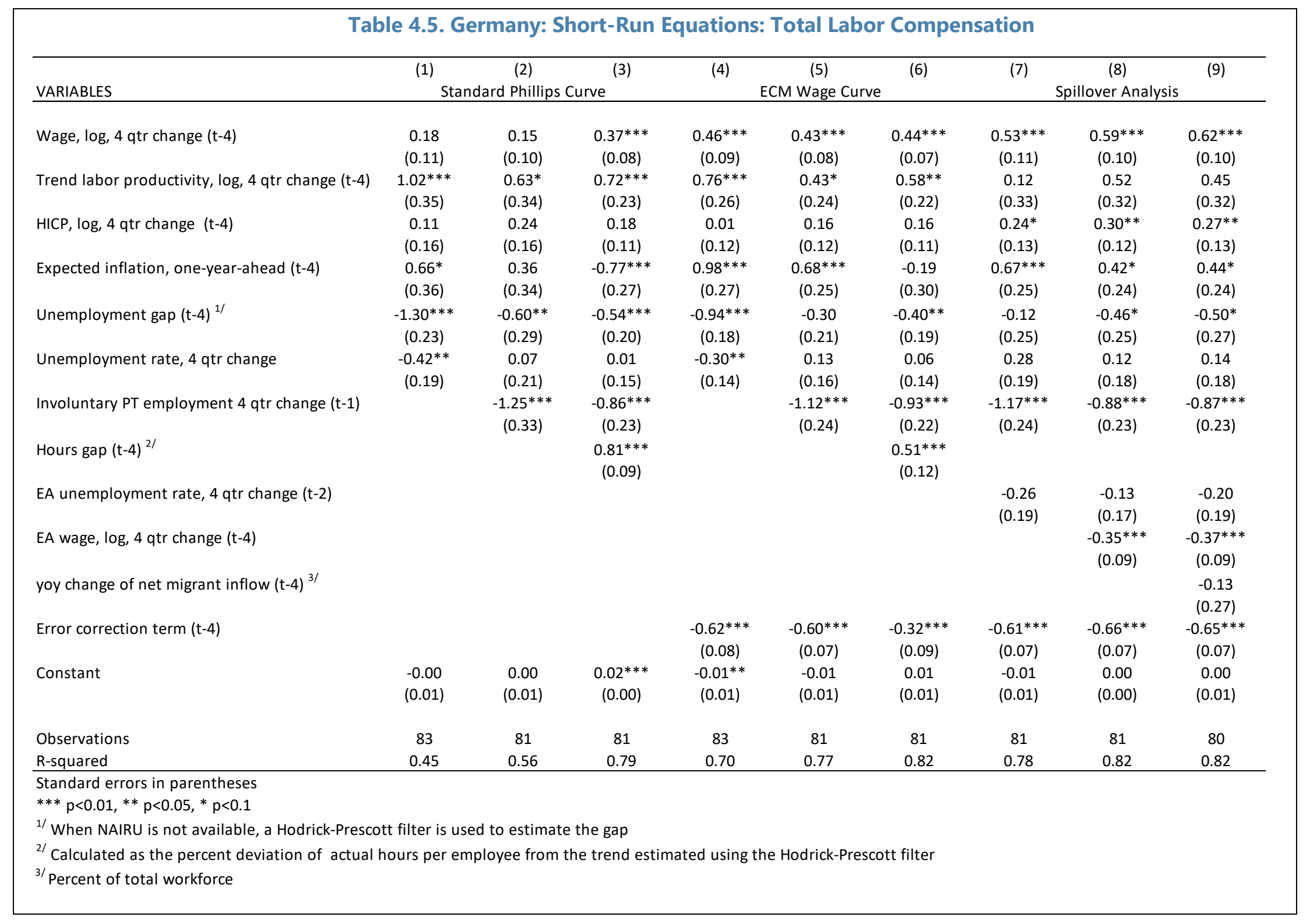

